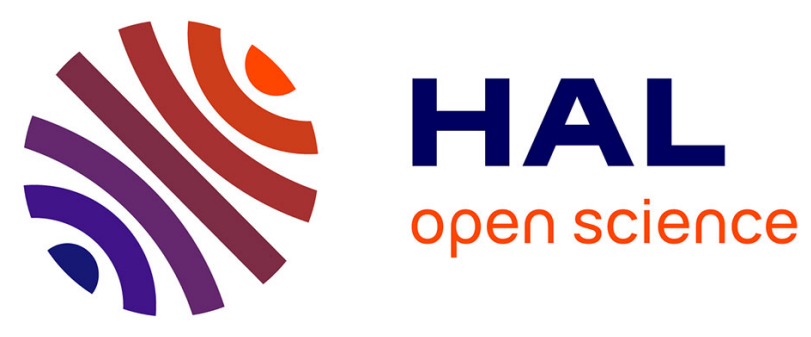

\title{
B-Ring-Modified isoCombretastatin A-4 Analogues Endowed with Interesting Anticancer Activities
}

\author{
Abdallah Hamze, Evelia Rasolofonjatovo, Olivier Provot, Céline Mousset, \\ Damien Veau, Jordi Rodrigo, Jérôme Bignon, Jian-Miao Liu, Joanna \\ Wdzieczak-Bakala, Sylviane Thoret, et al.
}

\section{To cite this version:}

Abdallah Hamze, Evelia Rasolofonjatovo, Olivier Provot, Céline Mousset, Damien Veau, et al.. BRing-Modified isoCombretastatin A-4 Analogues Endowed with Interesting Anticancer Activities. ChemMedChem, 2011, 6 (12), pp.2179-2191. 10.1002/cmdc.201100325 . hal-02394426

\section{HAL Id: hal-02394426 \\ https://hal.science/hal-02394426}

Submitted on 4 Dec 2019

HAL is a multi-disciplinary open access archive for the deposit and dissemination of scientific research documents, whether they are published or not. The documents may come from teaching and research institutions in France or abroad, or from public or private research centers.
L'archive ouverte pluridisciplinaire HAL, est destinée au dépôt et à la diffusion de documents scientifiques de niveau recherche, publiés ou non, émanant des établissements d'enseignement et de recherche français ou étrangers, des laboratoires publics ou privés. 


\title{
B-Ring Modified isoCombretastatin A-4 Analogues Endowed with Interesting Anticancer Activities
}

\author{
Abdallah Hamze,${ }^{[a]}$ Evelia Rasolofonjatovo, ${ }^{[a]}$ Olivier Provot, ${ }^{*[a]}$ Céline \\ Mousset, ${ }^{[a]}$ Damien Veau, ${ }^{[a]}$ Jordi Rodrigo, ${ }^{[a]}$ Jérôme Bignon, ${ }^{[b]}$ Jian- \\ Miao Liu, ${ }^{[b]}$ Joanna Wdzieczak-Bakala, ${ }^{[b]}$ Sylviane Thoret, ${ }^{[b]}$ Joëlle \\ Dubois, ${ }^{[b]}$ Jean-Daniel Brion, ${ }^{[a]}$ and Mouad Alami ${ }^{*}[\mathrm{a}]$
}

A novel class of isocombretastatin A-4 analogues with modifications on the 3'-position of the B-ring by replacement with C-substituents was studied. Exploration of the structure-activity relationships of theses analogues led to the identification of several compounds, which exhibited excellent antiproliferative activities at a nanomolar concentration against H1299, MDA-MB 231, HCT116 and K562 cancer cell lines, and inhibited tubulin polymerization similarly to isoCA-4. 1,1-Diarylethylenes $\mathbf{8}$ and $\mathbf{1 7}$ having on the 3'-position of the

\section{Introduction}

Microtubules are hollow tubes consisting of alternating $\alpha-$ and $\beta$ tubulin heterodimers found in almost all eukaryotic cells. They are involved in a variety of cellular functions, such as mitosis and cell replication, cell motility, and cell maintenance. Their importance for cellular life, and especially mitosis, makes them one of the prominent targets for the development of anticancer agents, and for the treatment of solid tumors. ${ }^{[1]}$ The dynamic process of assembly and disassembly of microtubules to tubulin is blocked by a variety of natura ${ }^{[2]}$ or synthetic agents ${ }^{[3]}$ that bind to distinct sites, such as binding sites for colchicines, paclitaxel and vinca alkaloids, resulting in mitotic arrest. Paclitaxel, for example, stabilizes microtubules and prevents their disassembly, whereas vincristine interacts with tubulin to inhibit its assembly. However, the problems of complex syntheses, high cytotoxicity associated with undesired side-effects, and lack of efficacy against multidrug resistance cancer cell lines encourage the development of new efficient antimitotic agents of low molecular weight. In this context, combretastatin A-4 (CA-4, 1a) a natural stilbene, isolated in 1989 by Pettit ${ }^{[4]}$ from the South African tree combretum caffrum, is one of most promising and more studied compounds (Figure 1). CA-4 strongly inhibited tumor cell growth, including multidrug resistant (MDR) cancer cell lines. ${ }^{[5]}$ This molecule binds at the colchicine binding site and inhibits tubulin polymerization at a micromolar level, ultimately leading to apoptosis. Moreover, CA4 also exerts highly selective effects in proliferating endothelial cells inducing irreversible vascular shutdown within solid
B-ring an (E)-propen-3-ol or propyn-3-ol substituent, respectively, proved to be the most active in this series. Both compounds led to the arrest of various cancer cell lines in the $G_{2} / M$ phase of the cell cycle and strongly induced apoptosis. A docking of molecules 8 and 17 inside the colchicine binding site was performed and indicated that their C-3' substituents guided the B-cycle in a different manner to that observed for isoCA-4.

tumors. ${ }^{[6]}$ Disodium phosphate CA-4P ${ }^{[7]}$ (1b) and AVE-8062 $2^{[8]}$ (1c), two water-soluble prodrug derivatives, are currently undergoing several advanced clinical trials for the treatment of age-related macular degeneration, ${ }^{[9]}$ anaplastic thyroid cancer ${ }^{[10]}$ and sarcoma. ${ }^{[11]}$ However, the main problem associated with these stilbenes is the ready isomerization of the (Z)-double bond into its $(E)$-inactive form. ${ }^{[12]}$ We have been actively engaged in searching novel tubulin inhibitors ${ }^{[13]}$ and have recently reported the synthesis ${ }^{[14]}$ and the biological evaluation of a new series of 1,1-diarylethylene derivatives with general structure 2. We demonstrated that the bioisosteric replacement of the (Z)-1,2ethylene by the 1,1-ethylene bridge resulted in retention of biological activities, solving de facto the (Z)-double bond isomerization problem. Results from these studies enabled identification of isoCA-4 (2a) as a lead compound, displaying the same activities as the natural product CA-4 (Figure 1). ${ }^{[13 a],[13 d]}$

[a] Dr. A. Hamze, Ms E. Rasolofonjatovo, Dr. O. Provot, Dr. C. Mousset, Mr D. Veau, Dr. J. Rodrigo, Pr. J ;-D. Brion, Dr. M. Alami Univ Paris-Sud, CNRS, BioCIS-UMR 8076, Laboratoire de Chimie Thérapeutique, Faculté de Pharmacie, 5 rue J.-B. Clément, Châtenay-Malabry, F-92296, France Fax:,+33(0)1.46.83.58.28, E-mail: olivier.provot@u-psud.fr । mouad.alami@u-psud.fr

[b] Dr. J. Bignon, Dr. J.-M. Liu, Dr. J. Wdzieczak-Bakala, Dr. S. Thoret, Dr. J. Dubois

Institut de Chimie des Substances Naturelles, UPR 2301, CNRS, avenue de la Terrasse, F-91198 Gif sur Yvette, France

Supporting information for this article is available on the WWW under http://www.chemmedchem.org or from the author.((Please delete if not appropriate)) 
Further structure-activity relationships (SAR) studies, led us to discover two other substances, iso $\mathrm{NH}_{2} \mathrm{CA}-4$ (2b) and isoFCA-4 (2c), which manifest biological activities comparable to that of isoCA-4 (Figure 1). ${ }^{[14 a]}$

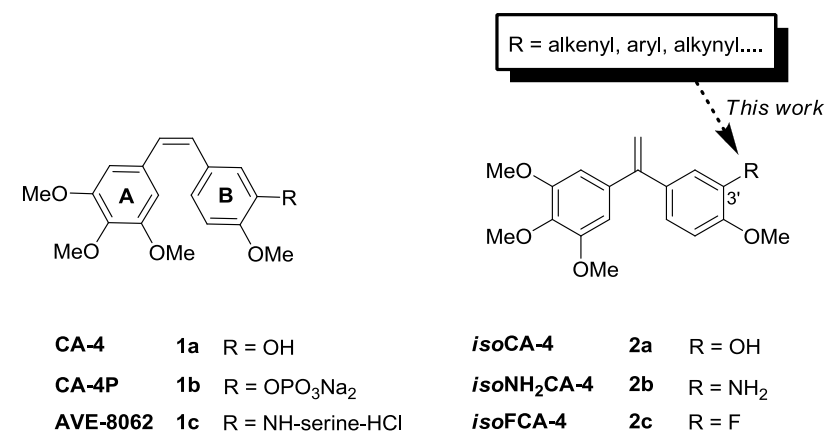

Figure 1. Rational drug design from CA-4 (1a) and isoCA-4 (2a) to $3^{\prime} \mathrm{C}$ substituted isoCA-4 analogues.

Since the 3'-position of isoCA-4 is amenable to bioisosteric modifications, we decided to further explore, the insertion of suitable substituents that could confer interesting pharmacological properties to isoCA-4, and to evaluate the steric and electronic effects of these substituents on antiproliferative activity. In this paper, we describe the syntheses and biological activities of novel isoCA-4 derivatives bearing an alkenyl-, aryl-, and alkynyl-substituent on the 3'-position of the B-ring. Except in a previous report on a 3-aroyl indazole series where alkyne chains replace the $\mathrm{OH}$ group, ${ }^{[15]}$ there are no reports disclosing similar modifications on the B-ring in the CA-4 series (introduction of 3'-Csp ${ }^{2}$ and Csp-substituents), probably because isomerization of the (Z)-double bond may occur during the chemical manipulations. ${ }^{[16]}$ In view of SAR studies, we have also prepared phenstatin $^{[3 c]}$ derivatives 38 and 39 bearing on the 3'-position various alkynol chains. Finally, we synthesized and examined the replacement of the $3^{\prime} \mathrm{OH}$-group of isoCA-4 with an azide, giving product $\mathbf{3 4}$ as a pivotal substrate for the generation of additional analogues 35-37 via the fashionable click-chemistry reaction. Potencies of newly synthesized compounds were evaluated using a primary cytotoxic screening assay against human colon carcinoma (HCT-116) cell lines. The most interesting derivatives were considered for further investigations, including cell proliferation against various cell lines, inhibition of tubulin polymerization (ITP), cellular cycle analysis, in addition to their ability to induce apoptosis.

\section{Results and Discussion}

\section{Chemistry}

To achieve our goal, we initially focused on the synthesis of diarylethylene derivative 5 having an iodine atom on 3'-position as a valuable substrate in $\mathrm{C}-\mathrm{C}$ bond-forming reactions through $\mathrm{Pd}$-catalyzed reactions. As shown in Scheme 1, 5 was prepared in a three-step sequence by reaction of $3,4,5$ trimethoxyphenylmagnesium bromide with 3-iodo-4methoxybenzaldehyde in THF. The resulting alcohol $\mathbf{3}$ was converted to benzophenone $\mathbf{4}$ by treatment with PCC.
Subsequent Wittig reaction of methyltriphenylphosphonium bromide with 4 in THF in the presence of LiHMDS to generate the ylide led to $\mathbf{5}$ in a good overall yield. With this key intermediate in hand, we subjected the C-I bond to Pd-catalyzed C-C bond formation under typical Heck, Suzuki and Sonogashira reaction conditions. Thus, reaction of $\mathbf{5}$ with methyl acrylate provided selectively 3'-methyl $(E)$-cinnamate derivative $\mathbf{6}$, which underwent saponification under alkaline conditions to afford cinnamic acid 7 in a good yield. To preserve the two carbon-carbon double bonds of methyl cinnamate 6 , the reduction of the ester function was achieved with DIBAH at $-78{ }^{\circ} \mathrm{C}$ and furnished $(E)$-allylic alcohol 8 . Next, to introduce an aryl substituent, we examined Suzuki couplings between various substituted arylboronic acids and $\mathbf{5}$. The reactions proceeded smoothly in the presence of $\mathrm{Pd}\left(\mathrm{PPh}_{3}\right)_{4}$ and $\mathrm{NaHCO}_{3}$ in $\mathrm{DME}-\mathrm{H}_{2} \mathrm{O}$ under reflux to give the corresponding coupling products $\mathbf{9 - 1 6}$ in satisfactory yields (51 to $78 \%$ ).

The synthesis of acetylenic isoCA-4 analogues was achieved from 5 using standard Sonogashira-Linstrumelle coupling reactions. ${ }^{[17]}$ Accordingly, a small library of alkyne derivatives 1726 was obtained in satisfactory to good yields. In order to evaluate the impact on biological activity of various modifications on the 3'-position, the triple bond of acetylenic isoCA-4 analogues provides a focal point for further structural manipulations. Thus, hydration of arylalkynols 17-20 was regioselectively achieved in the presence of a catalytic amount of $p$-toluensulfonic acid in boiling $\mathrm{EtOH}$. Under this environmentally metal-free procedure, developed by our group, ${ }^{[18]}$ arylketones 27-30 were obtained in good yields. As expected and previously reported by us, ${ }^{[18],[19]}$ aliphatic arylalkynol substrates 17-19 having a propyn-3-ol, butyn4-ol or pentyn-5-ol chain, were subsequently etherified by solvent to ether derivatives 27-29. Under similar conditions, ${ }^{[19]}$ isoCA-4 analogues 24-26 having an o-methoxydiarylalkyne moiety underwent a regioselective 5 -endo-dig-cyclization ${ }^{[20]}$ to give 2aryl-substituted benzofurans $\mathbf{3 1 - 3 3}$ as single products in excellent yields. ${ }^{[21]}$

Finally, the synthesis of isoCA-4 analogues bearing a triazole ring at the 3'-position involved the preparation of the azide iso $\mathrm{N}_{3} \mathrm{CA}-4$ (34), which might also be used as photoaffinity labeling reagent for the colchicine site on $\beta$-tubulin. ${ }^{[16 b],[22]}$ Thus, reaction of isolCA-4 with $\mathrm{NaN}_{3}$ in the presence of Cul (10 mol\%), DMEDA (15 mol\%), potassium ascorbate ( $5 \mathrm{~mol} \%$ ) in $\mathrm{DMSO}-\mathrm{H}_{2} \mathrm{O}$ at various temperatures led to a mixture of the desired azide $\mathbf{3 4}$ together with iso $\mathrm{NH}_{2} \mathrm{CA}-4$ in variable ratios, despite extensive experimentation. ${ }^{[23]}$ In order to optimize the yield of iso $\mathrm{N}_{3} \mathrm{CA}-4$, we exploited the Sandmeyer diazotization of iso $\mathrm{NH}_{2} \mathrm{CA}-4$ (2b) in the presence of $\mathrm{NaNO}_{2}$ and $\mathrm{NaN}_{3}$ under acidic medium. Accordingly, azide 34 was obtained in a good $85 \%$ yield. Further Huisgen cycloaddition with various terminal alkynes under standard conditions furnished triazole-substituted isoCA-4 analogues 35-37 in good to excellent yields (Scheme 2).

Because of the potent cancer cell line growth inhibition displayed by benzophenone derivatives, named phenstatins, we prepared for SAR studies, two phenstatin analogues $\mathbf{3 8}$ and $\mathbf{3 9}$ bearing on the 3'-position a propyn-3-ol and butyn-4-ol chain, respectively (Scheme 3 ). 

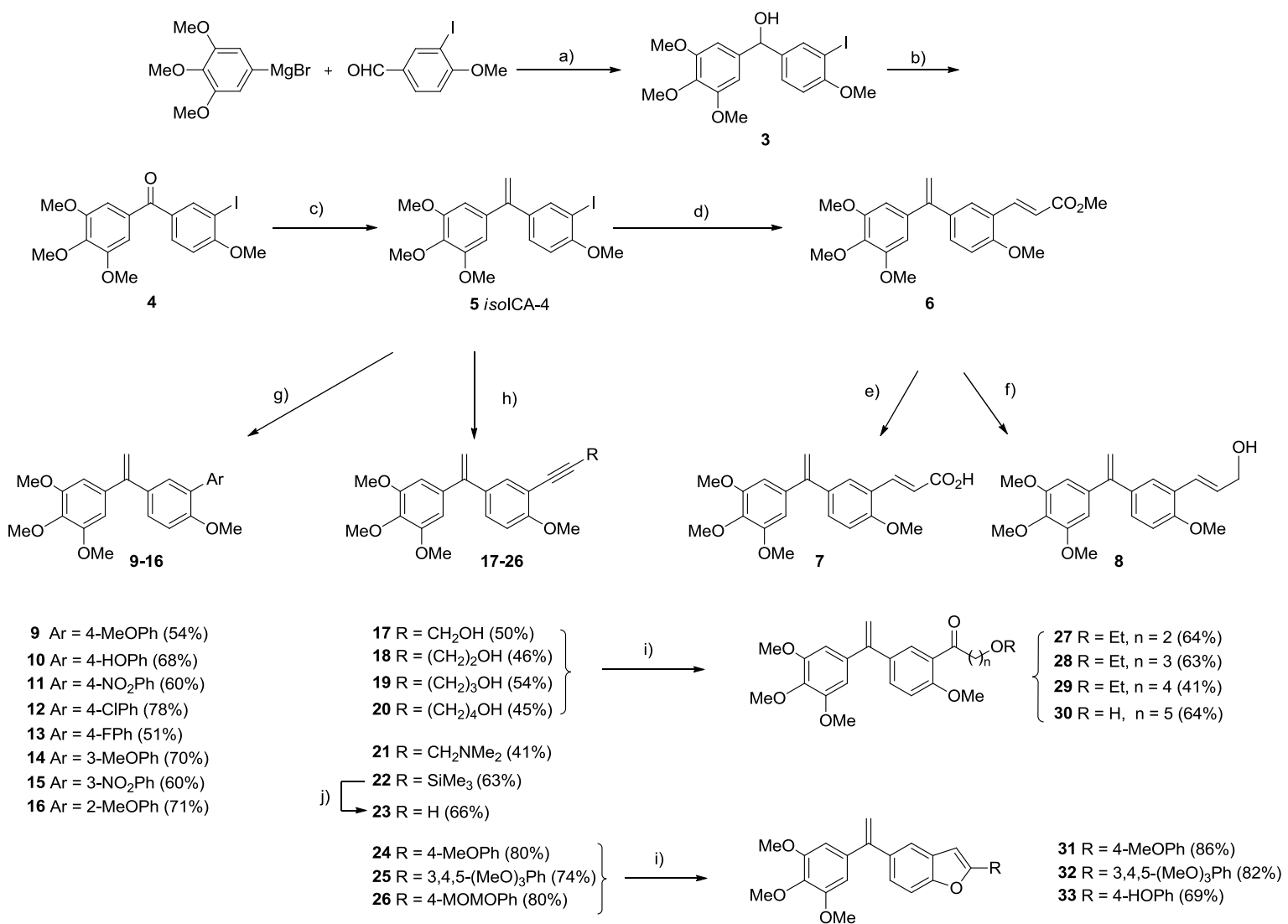

Scheme 1. Reagents and conditions: a) THF, -78 to $20{ }^{\circ} \mathrm{C}, 90 \%$; b) $\mathrm{PCC}, \mathrm{CH}_{2} \mathrm{Cl}_{2}$, rt, $85 \%$; c) $\mathrm{MePPh}_{3} \mathrm{Br}$, $\mathrm{LiHMDS}, \mathrm{THF},-78{ }^{\circ} \mathrm{C}, 90 \%$; d) $\mathrm{Methyl}$ acrylate, $\mathrm{PdCl}_{2}\left(\mathrm{PPh}_{3}\right)_{2}, \mathrm{Et}_{3} \mathrm{~N}, \mathrm{DMF}, 60{ }^{\circ} \mathrm{C}, 64 \%$; e) $\mathrm{NaOH}, \mathrm{MeOH}, \mathrm{rt}, 70 \%$; f) DIBAH, THF, $\left.\left.-78{ }^{\circ} \mathrm{C}, 40 \% ; \mathrm{g}\right) \mathrm{ArB}(\mathrm{OH})_{2}, \mathrm{Pd}(\mathrm{PPh})_{4}, \mathrm{NaHCO}, \mathrm{DME}-\mathrm{H}_{2} \mathrm{O}, \mathrm{reflux} ; \mathrm{h}\right) 1-\mathrm{Alkyne}$, $\mathrm{PdCl}_{2}\left(\mathrm{PPh}_{3}\right)_{2}, \mathrm{Cul}, \mathrm{Et}_{3} \mathrm{~N}, \mathrm{THF}$; i) PTSA, EtOH, microwave, $170{ }^{\circ} \mathrm{C}$; j) TBAF, THF, rt.

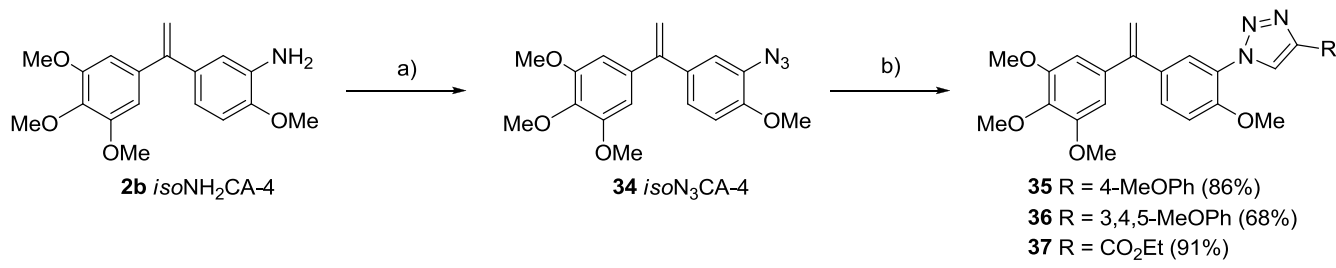

Scheme 2. Reagents and conditions: a) $\mathrm{NaNO}_{2}, \mathrm{HCl}_{\mathrm{aq}}, \mathrm{NaN}_{3}$, acetone, $0{ }^{\circ} \mathrm{C}, 85 \%$; b) 1-Alkyne, $\mathrm{CuSO}_{4} \cdot 5 \mathrm{H}_{2} \mathrm{O}$, potassium ascorbate, $t \mathrm{BuOH}-\mathrm{H}_{2} \mathrm{O}, 70{ }^{\circ} \mathrm{C}$.
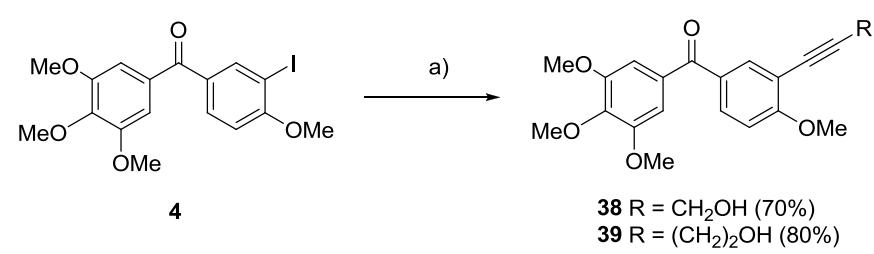

Scheme 3. Reagents and conditions: a) 1-Alkynol, $\mathrm{PdCl}_{2}\left(\mathrm{PPh}_{3}\right)_{2}, \mathrm{Cul}, \mathrm{Et}_{3} \mathrm{~N}$, THF.

\section{Biology.}

\section{In vitro cell growth inhibition assay}

All the synthesized compounds were tested in a preliminary growth inhibition assay on HCT-116 cells, a human colon carcinoma cell line, using CA-4 and isoCA-4 as reference compounds. The $\mathrm{GI}_{50}$ values (the drug concentration that reduced cell growth by $50 \%$ ) of isoCA-4 analogues are listed in Table 1. The results presented in Table 1 clearly reveal that the size of the substituent on the 3'-position plays a critical role in cell growth inhibition. First, 5 was evaluated and showed a promising antiproliferative activity with $\mathrm{Gl}_{50}=300 \mathrm{nM}$. Next, 1,1diarylethylene compounds 6-8 bearing 3'-alkenyl substituents on the B-ring exhibited significative antiproliferative activities with $\mathrm{Gl}_{50}$ values ranging from 45 to $80 \mathrm{nM}$. Introduction of a series of substituted-benzene rings (9-16) on the 3'-position resulted in an important decrease in cytotoxicity, probably for steric considerations. Evaluation of acetylenic isoCA-4 analogues 17-26 was then examined. When small acetylenic chains were introduced onto the 3'-position, the resulting propargyl alcohol 17 and terminal arylalkyne $\mathbf{2 3}$ were found to be the most cytotoxic agents against HCT-116 cells $\left(\mathrm{Gl}_{50}=30 \mathrm{nM}\right)$. Only a slight loss of activity was observed when the acetylenic chain was increased by one or two carbons (e.g.; compounds 18 and 19). However, compounds bearing a longer alkynol chain 20 or having a propargyl amino function $\mathbf{2 1}$ resulted in significant reduction in cancer cell growth inhibition, whereas derivatives 24-26, with arylalkyne substituents, were not active. 


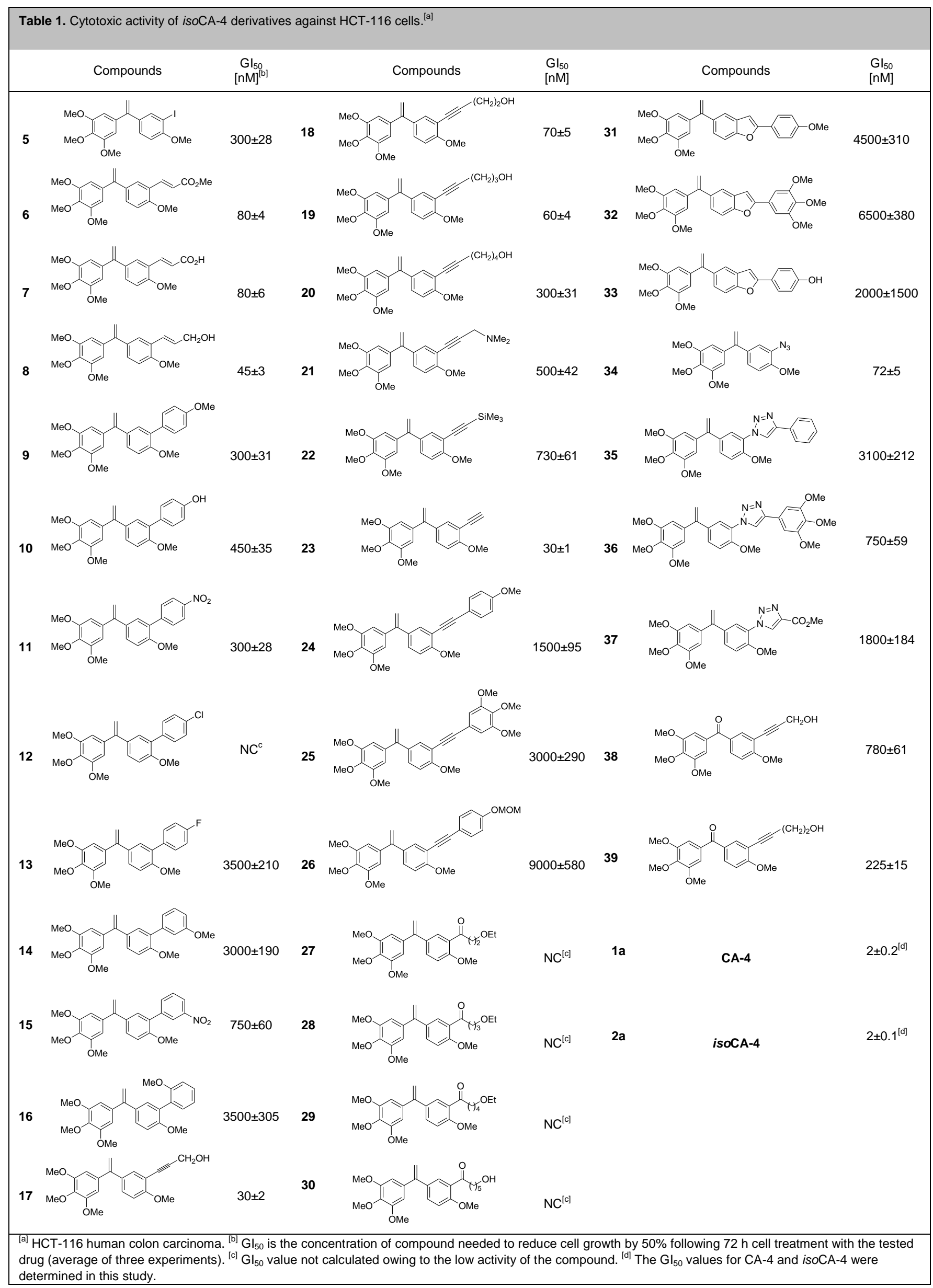


These observations reveal, from one hand, that steric effects at the 3'-position of the B-ring influence cytotoxic activities and, on the other hand, that $\mathrm{C}$-substitutions are very well tolerated.

Arylketone derivatives $\mathbf{2 7 - 3 0}$ in which the carbonyl is located at the C-3' are not cytotoxic. Benzofuran-containing isoCA-4 analogues $31-33$ resulting from the cyclization of compounds 24-26 displayed a weak antiproliferative effect against HCT-116 cells. Triazole derivatives $\mathbf{3 5 - 3 7}$ exhibited only modest antiproliferative activity, whereas their azide precursor iso $\mathrm{N}_{3} \mathrm{CA}-4$ (34) had a significantly improved cytotoxicity $\left(\mathrm{Gl}_{50}=72\right.$ $\mathrm{nM})$, supporting the idea that small C- or $\mathrm{N}$-substituents, are welcome on the 3'-position. Finally, for comparison purposes, 3'alkynol phenstatins (38 and 39) and their isocombretastatin homologues (17 and $\mathbf{1 8}$ ) were evaluated. The cytotoxic activity of 38 and 39 was considerably reduced (from 30 to $780 \mathrm{nM}$ and 70 to $225 \mathrm{nM}$, respectively), emphasizing the increased therapeutic potency of isocombretastatin A-4 derivatives compared to their phenstatin homologues.

To characterize the cytotoxicity profiles of these compounds we investigated the effect of the most active substances $6,7,8$, $17,18,19,23$ and $34\left(\mathrm{Gl}_{50}<80 \mathrm{nM}\right)$ on the proliferation of three other tumor cell lines: H1299 human non-small cell lung carcinoma, K562 myelogenous leukemia cancer cells and MDAMB231 human hormone-independent breast cancer cells. The screening results revealed that all selected compounds strongly inhibited the growth of all examined tumor cell lines, and this effect did not depend on the cell type (Table 2). It is noteworthy that the $\mathrm{Gl}_{50}$ values obtained with allylic alcohol 8 were comparable with those of CA-4 and isoCA-4 ranging between 2 and $5 \mathrm{nM}$. Interestingly, other modifications at the 3'-position with small C- substituents on the B-ring led to promising antiproliferative properties, particularly against HCT-116, K562 and $\mathrm{H} 1299$ cancer cell lines. Similarly, azide $\mathbf{3 4}$ was as active as its $\mathrm{C}$-substituted congeners.

\begin{tabular}{|c|c|c|c|c|c|}
\hline \multirow[b]{2}{*}{ Compound } & \multicolumn{4}{|c|}{ Cytoxicity $\mathrm{GI}_{50}(\mathrm{nM})^{[\mathrm{a}]}$} & \multirow[t]{2}{*}{ ITP IC $\mathrm{C}_{50}(\mu \mathrm{M})^{[\mathrm{cl}]}$} \\
\hline & HCT116 ${ }^{[b]}$ & $\mathrm{K} 562^{[\mathrm{b}]}$ & $\mathrm{H} 1299^{[b]}$ & $\begin{array}{c}\text { MDA- } \\
\text { MB231 }^{[\mathrm{b}]}\end{array}$ & \\
\hline 6 & $80 \pm 4$ & $80 \pm 2$ & $70 \pm 3$ & $500 \pm 28$ & $2.4 \pm 0.4$ \\
\hline 7 & $80 \pm 6$ & $80 \pm 2$ & $70 \pm 4$ & $500 \pm 35$ & $3.1 \pm 0.5$ \\
\hline 8 & $45 \pm 3$ & $2 \pm 0.1$ & $5 \pm 0.3$ & $5 \pm 0.4$ & $2.3 \pm 0.2$ \\
\hline 17 & $30 \pm 2$ & $35 \pm 1$ & $25 \pm 2$ & $7 \pm 0.3$ & $2.0 \pm 0.4$ \\
\hline 18 & $70 \pm 5$ & $90 \pm 4$ & $25 \pm 2$ & $500 \pm 25$ & $3.8 \pm 0.3$ \\
\hline 19 & $60 \pm 4$ & $80 \pm 5$ & $70 \pm 4$ & $100 \pm 16$ & $0.9 \pm 0.1$ \\
\hline 23 & $30 \pm 1$ & $20 \pm 3$ & $35 \pm 2$ & $30 \pm 3$ & $67 \pm 9$ \\
\hline $34\left(\right.$ iso $\left._{3} \mathrm{CA}-4\right)$ & $72 \pm 5$ & $28 \pm 2$ & $50 \pm 3$ & $30 \pm 1$ & $3.4 \pm 0.3$ \\
\hline $1 \mathrm{a}(\mathrm{CA}-4)^{[\mathrm{da}]}$ & $2 \pm 0.2$ & $4 \pm 0.2$ & $5 \pm 0.3$ & $3 \pm 01$ & $2 \pm 0.1$ \\
\hline $2 \mathrm{a}(\text { isoCA-4) })^{[\mathrm{d}]}$ & $2 \pm 0.1$ & $5 \pm 0.2$ & $5 \pm 0.1$ & $4 \pm 0.1$ & $1.5 \pm 0.2$ \\
\hline
\end{tabular}

\section{Inhibition of tubulin polymerization (ITP)}

To investigate whether the antiproliferative activities of these compounds were related to the interaction with the microtubule system, they were evaluated for the inhibition of the assembly of tubulin. This was purified from sheep brains according to a slightly modified Guénard's protocol. ${ }^{[24]}$ With the exception of terminal alkyne $\mathbf{2 3}$, all selected compounds inhibited tubulin polymerization with $\mathrm{IC}_{50}$ values of 2 to $4 \mu \mathrm{M}$ (Table 2). Although the antiproliferative activities of compounds $6,7,17,18$, 19 and 34 were slightly weaker than that of isoCA-4, their antitubulin activities are similar to those of the reference molecule. One can note that compound $\mathbf{8}$, bearing on the 3'-position an allylic alcohol function was as active as isoCA-4, with respect to cytotoxicity and inhibition of tubulin polymerization. The interesting biological results obtained with compounds $\mathbf{8}$ and $\mathbf{1 7}$, in which the $3^{\prime}-\mathrm{OH}$ group of isoCA-4 is replaced by an (E)-propen3-ol or propyn-3-ol substituent, respectively, demonstrate that structural alteration at this part of isoCA-4 offers interesting premises for the design of novel and potent drugs for cancer therapy.

\section{Cell Cycle Analysis and Apoptosis}

Tubulin assembly inhibitors often cause alteration of cell cycle parameters, with preferential $G_{2} / M$ blockade. Therefore, flow cytometry analysis was performed with our lead compounds 8 and 17 on H1299, MDA-MB231, HCT-116 and K562 cells and analyzed $24 \mathrm{~h}$ after treatment in the presence of increasing amounts of 8 and $\mathbf{1 7}(5,10$, and $50 \mathrm{nM})$. 


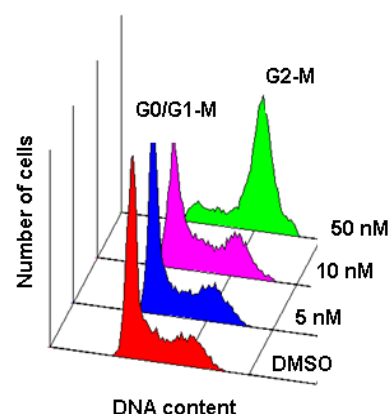

Compound 17

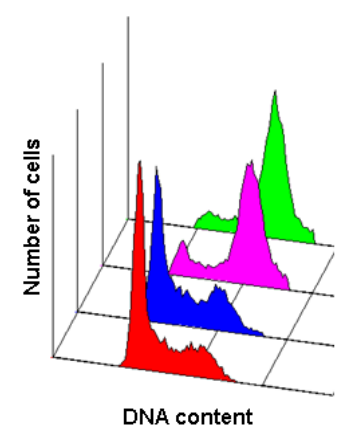

Compound 8

H1299 cells

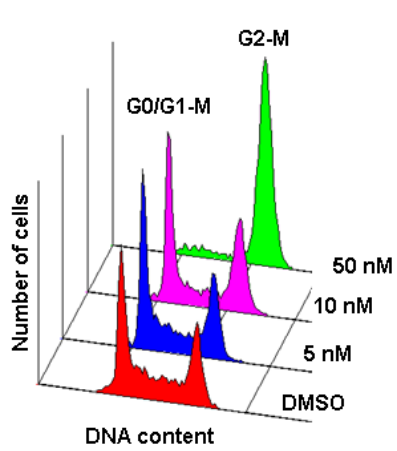

Compound 17

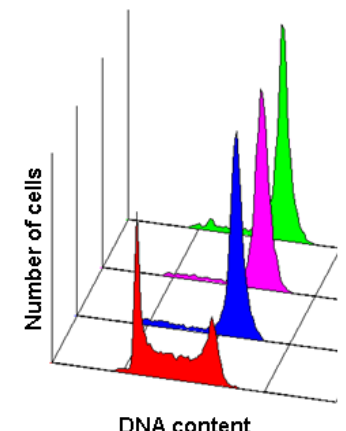

Compound 8

HCT-116

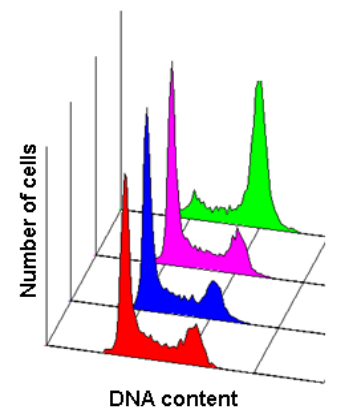

Compound 17

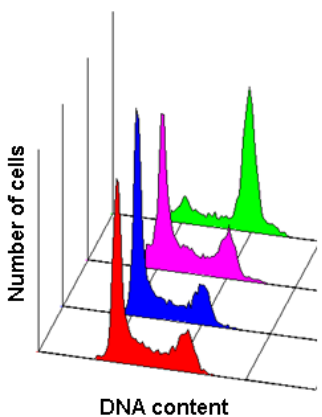

Compound 8
MDA-MB231
Compound 17

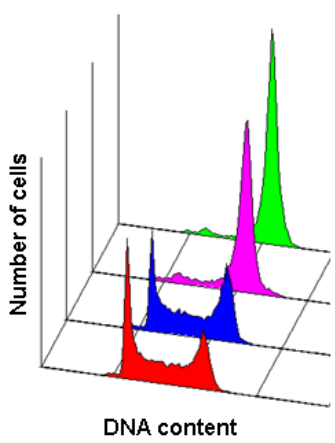

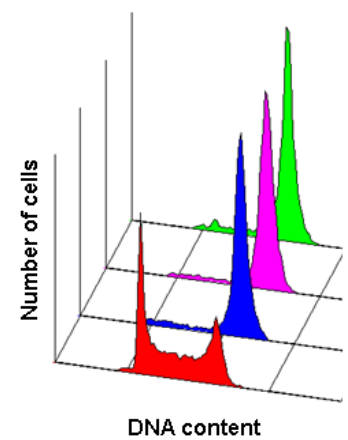

Compound 8
K562

Figure 2. Effect of selected drugs $\mathbf{8}$ and $\mathbf{1 7}$ on cell cycle distribution in various cancer cell lines determined by flow cytometry analysis. DNA content was assessed via propidium iodide staining.

Analysis of Figure 2 revealed that these compounds caused a massive cell accumulation in the $\mathrm{G}_{2} / \mathrm{M}$ phase when these drugs were used at a $50 \mathrm{nM}$ concentration. At a lower concentration of $10 \mathrm{nM}$, compound 8 was still efficient with H1299, HCT116 and $\mathrm{K} 562$ cell lines and arrested the majority of cells in $\mathrm{G}_{2} / \mathrm{M}$ phase of the cell cycle. It is to note that MDA-MB231 cells were slightly less sensitive to these drugs and their effect on the cellular cycle was noticeable only at a $50 \mathrm{nM}$ concentration. On the contrary, at a low $5 \mathrm{nM}$ concentration, both compounds 8 and 17 accumulated $\mathrm{K} 562$ cells at $\mathrm{G}_{2} / \mathrm{M}$. The observed effects of $\mathbf{1 7}$ and particularly of $\mathbf{8}$ on cell cycle progression with all the cancer cell lines correlated well with their strong antiproliferative and antitubulin activities (Tables 1 and 2). This result is in agreement with the similar properties reported previously for the majority of antimitotic agents.Cell-cycle arrest in the $G_{2} / M$ phase is frequently followed by DNA fragmentation and other morphological features of apoptosis. Therefore, we investigated the effect of compounds 8 and 17 at various concentrations $(5,10$, and $50 \mathrm{nM})$ on the induction of apoptosis in HCT-116, MDA-MB231, and H1299 cancer cells using standard assays for caspases 3 and 7. ${ }^{[25]}$ The enzymatic activity of caspases 3 and 7 was measured by monitoring the cleavage of the fluorogenic substrate Z-DEVD$\mathrm{R} 110$ in cancer cells. The results presented in Figure 3 show a significant dose-dependent increase in proteolytic activity of both examined caspases in the cells treated for $24 \mathrm{~h}$ with the two studied substances. Figure 3 reveals that allylic alcohol 8 is more prone at inducing apoptosis than its propargylic analogue 17. One can note that these two apoptotic agents were very efficient against all the tested cancer cell lines with notably, a significative efficiency against $\mathrm{H} 1299$ cells at very low concentrations (from 5 to $10 \mathrm{nM}$ ). These results clearly indicate that, in addition to their antiproliferative and antitubulin effects, the treatment of cancer cells with these drugs $\mathbf{8}$ and 17, activate caspase systems leading to programmed cell death.

To rationalize the binding modes of this new series of isoCA-4 analogues inside the tubulin binding site, docking studies were carried out with the most active molecules 6, 8, 17 and 18. For this purpose, the X-ray structure of tubulin cocrystallized with $\mathrm{N}$ deacetyl- $N$-(2-mercaptoacetyl)colchicine (DAMA-colchicine, PDB: $1 \mathrm{sa} 0)^{[26]}$ was used. Taking in consideration the big size of our new tubulin ligands due to their C3'-substituents, we envisioned another binding mode that could accommodate these molecules into the colchicine binding site. Figure 4a illustrates molecules 6 , 8, 17 and 18 docked in the colchicine-binding site of tubulin, and all of them overlap well. Moreover, the binding of these compounds to tubulin was stabilized by hydrogen bonding interactions with Cys241 (residue numbering derived from the crystal structure). The results of our docking studies, in which the trimethoxyphenyl ring of selected compounds is well positioned in the vicinity of Cys241, are consistent with previous reports concerning DAMA-colchicine ${ }^{[26]}$ and CA-4 analogues ${ }^{[27]}$ that displayed strong antitubulin activities. However, as observed in Figure 4b, compounds 6, 8, 17 and 18 showed a binding pose different to the one observed with the co-crystallized DAMAcolchicine as well as isoCA-4, and clearly docked in another pocket. On the contrary to previous works where the $3{ }^{\prime} \mathrm{OH}$ substituent belonging to CA-4 analogues showed a strong 
hydrogen bond with the backbone nitrogen of Val181, this hydrogen bond was completely lost with compounds $6,8,17$ and<smiles>C=C(c1ccc(OC)c(OC)c1)c1ccc(OC)c(OC)c1</smiles>

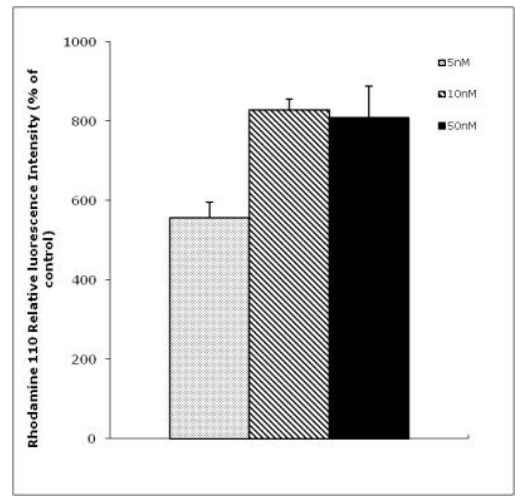

HCT116

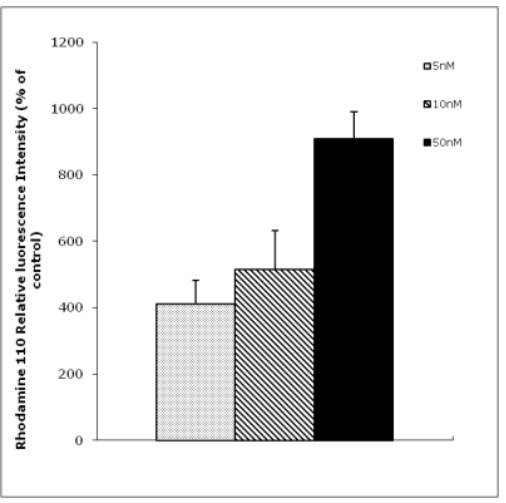

MDA-MB231

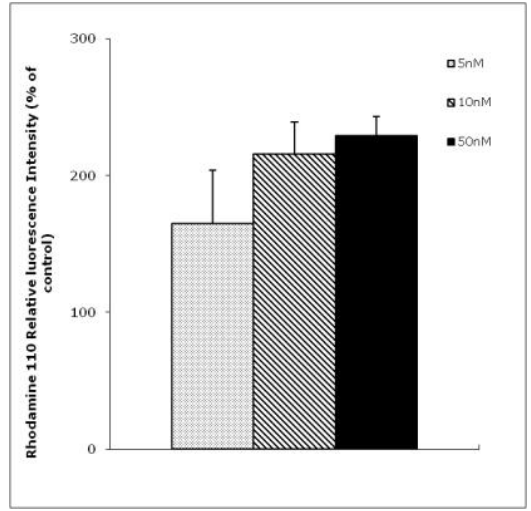

HCT116

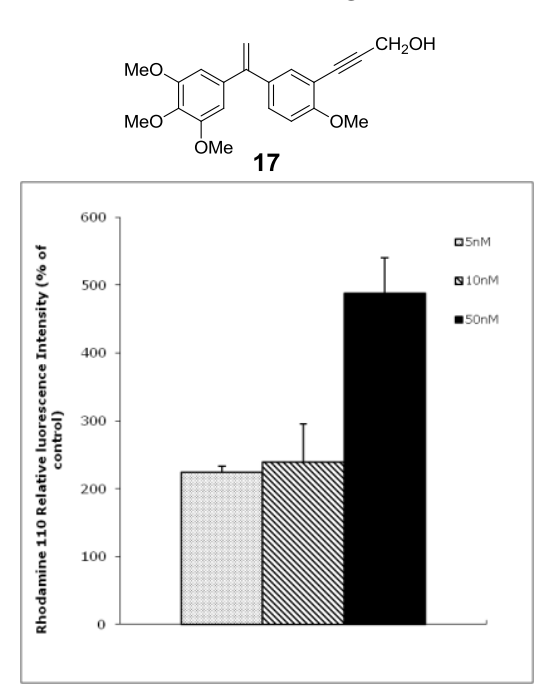

MDA-MB231

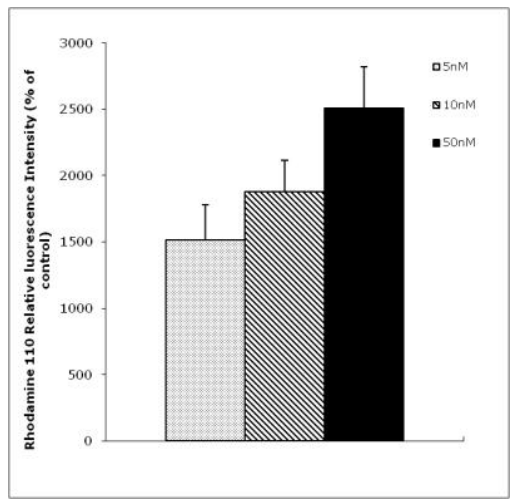

H1299

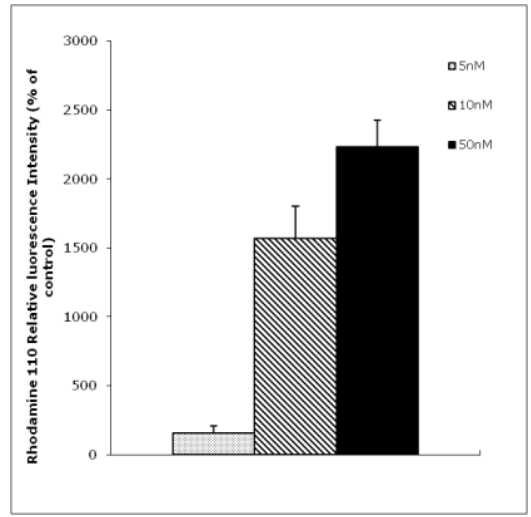

H1299

Figure 3. Apoptotic effects of selected compounds $\mathbf{8}$ and $\mathbf{1 7}$ in HCT-116, MDA-MB231 and H1299 cells. Results are expressed as a percentage of apoptotic cells detected following $24 \mathrm{~h}$ of treatment with $\mathbf{8}$ and $\mathbf{1 7}$ at different concentrations as indicated

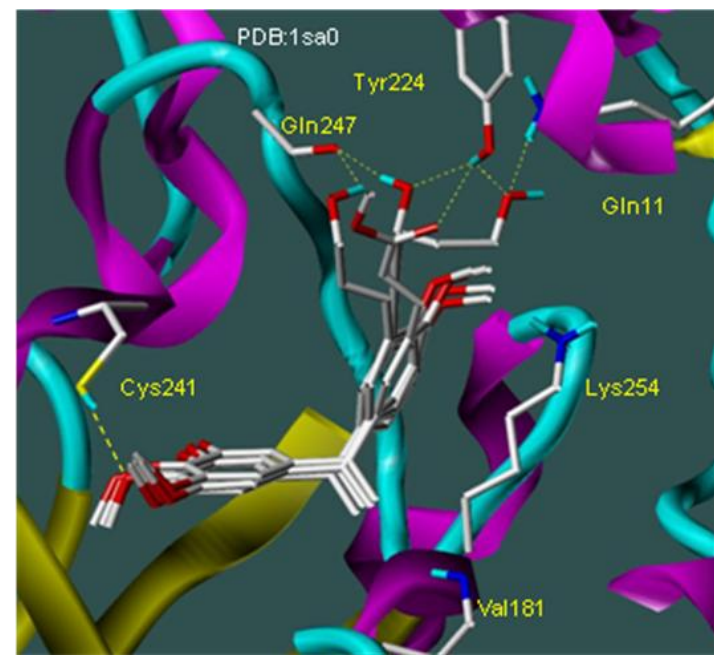

Figure 4a. Superimposition of molecules 6, 8, 17 and 18 into the colchicine binding site.

Although the trimethoxyphenyl moiety remains anchored at the same place in proximity of Cys241, a polar cavity formed by Gln247, Tyr224, Gln11 and Lys254 accommodates the C3'-

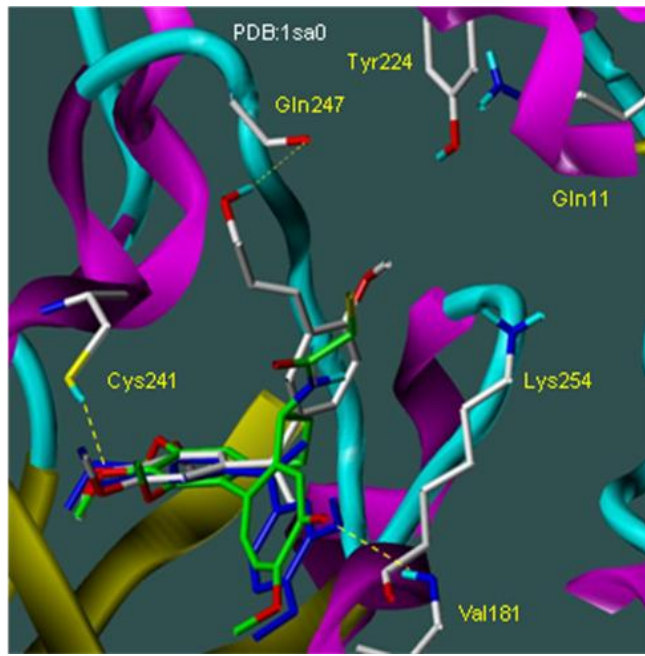

Figure $\mathbf{4 b}$. Superimposition of $\mathbf{8}$ (silver), DAMA-colchicine (green) and isoCA-4 (blue) in the colchicine binding site.

substituents of the B-ring in molecules 6, 8, 17 and 18. In detail, 6 forms a hydrogen bond with Tyr224, and 8 with the backbone carbonyl of Gln247, whereas 17 and 18 form a double hydrogen 
bond with Gln247 and Tyr224, and with Tyr224 and Gln11, respectively (Figure 5). Moreover, the 4'-methoxy group of each molecule attached to the B-ring is seen to establish an additional extra hydrogen bond with Lys254 (not displayed in the image). These original binding modes may rationalize the potency

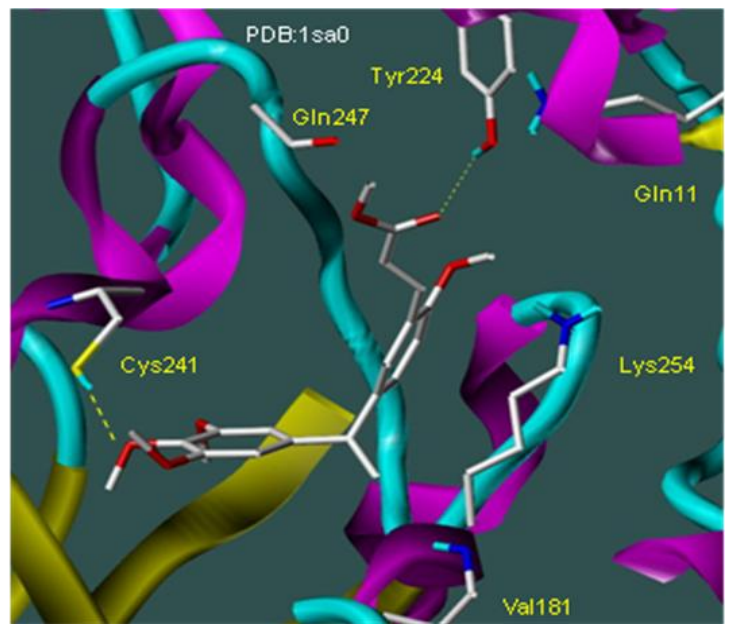

Compound 6

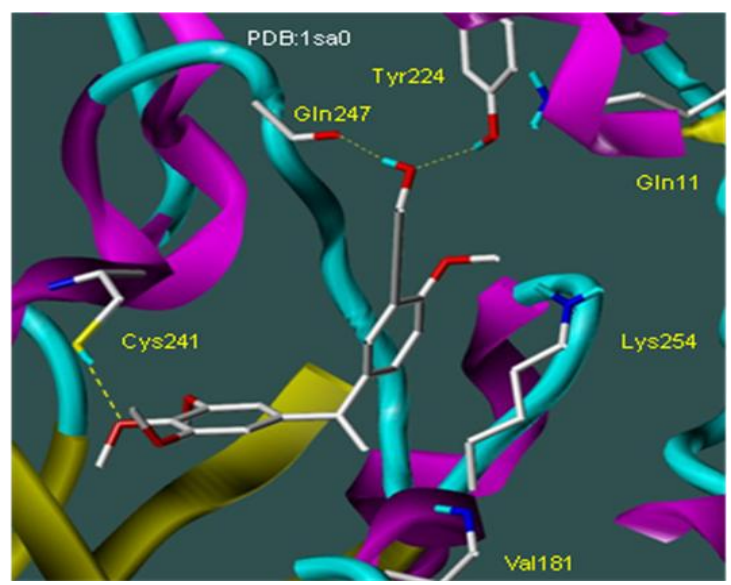

Compound 17 observed for our molecules in their inhibition of tubulin polymerization. From all of these considerations, we are planning to rationalize the synthesis of new isoCA-4 analogues in order to achieve better interactions with this polar cavity formed by Gln247, Tyr224, Gln11 and Lys254.

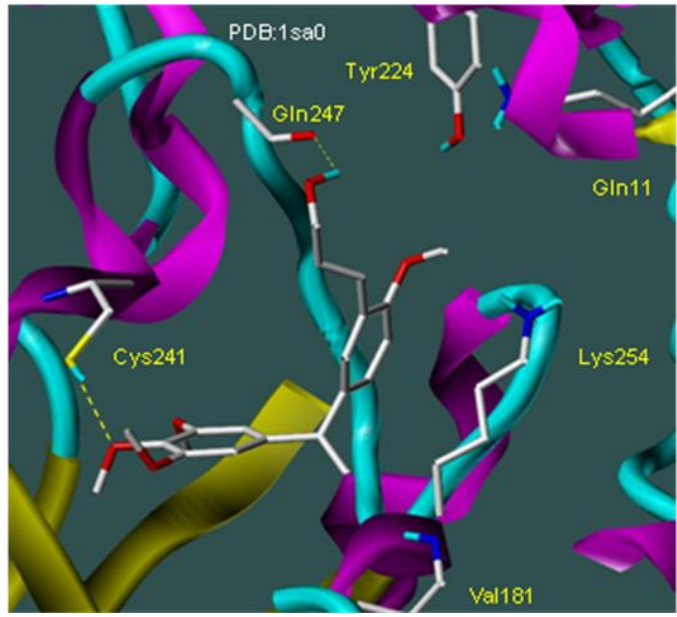

Compound 8

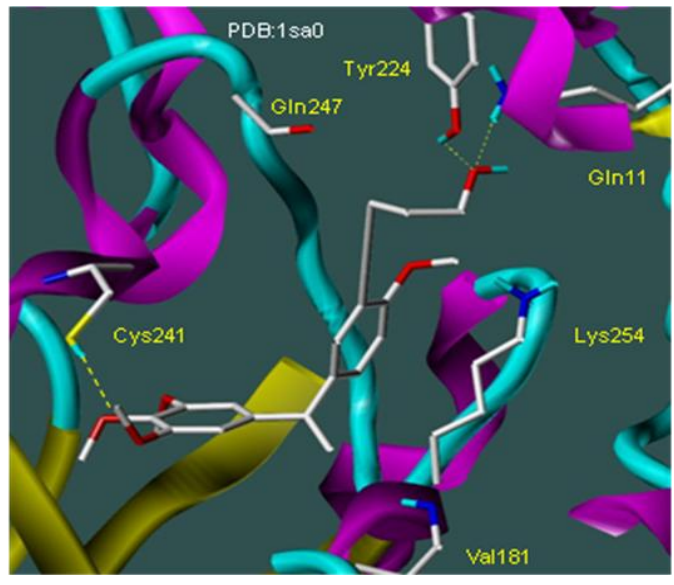

Compound 18

Figure 5: Presumptive docked pose of 6, 8, 17 and 18 in colchicine binding site of tubulin with significant binding residue Cys241, Gln247, Tyr224, Gln11 and Lys254.

\section{Conclusion}

In continuing experiments to optimize the isoCA-4 skeleton, we have synthesized and biologically evaluated a novel series of 1,1diaryl compounds in which the 3'-OH moiety of isoCA-4 was replaced with various C-substituents (e.g.; aryl, alkenyl, alkynyl,...). From these SAR studies, compounds 8 and 17 bearing an allylic and a propargylic alcohol function on the C-3' position, respectively, were found to display the most potent antiproliferative activity against a panel of cancer cell lines at a nanomolar level. The investigation of the mechanism of action by which these compounds exert their antiproliferative activity revealed that compounds $\mathbf{8}$ and $\mathbf{1 7}$ were potent inhibitors of tubulin polymerization with $\mathrm{IC}_{50}$ of $2 \mu \mathrm{M}$. In addition, they affected cell cycle progression of H1299, MDA-MB 231, HCT-116 as well as $\mathrm{K} 562$ cancer cells, and resulted in cell cycle arrest in the $\mathrm{G}_{2} / \mathrm{M}$ phase. IsoCA-4 derivatives 8 and 17 have also been characterized as strong apoptotic agents at low concentrations by inducing cleavage of pro-caspases-3 and 7 in H1299, MDA-MB 231 and HCT-116 cells. These findings enlarge the knowledge of the SAR of the 1,1-diarylethylene derivatives, which are different than those displayed by the related phenstatin compounds.
Modeling studies indicate a possible original binding-mode for these inhibitors of tubulin polymerization. It was showed that the binding of these compounds to $\beta$-tubulin was directed by their $\mathrm{C}$ 3' substituents and was stabilized by hydrogen-bonding interactions in a new polar cavity formed with Cys241, Gln247, Tyr224, Gln11 and Lys254. This observation, the easy synthetic access and the excellent biological results obtained with structural changes at C-3' position of isoCA-4 demonstrate that modifications at this portion are promising for the design of novel and potent isoCA-4 analogues.

\section{Experimental Section}

\section{Chemistry}

Melting points (m.p.) were recorded on a Büchi B-450 apparatus and were uncorrected. NMR spectra were performed on a Bruker AVANCE 300. Chemical shifts $\delta$ are in ppm, and the following abbreviations are used: singlet (s), (br s), broad singlet, doublet (d), triplet $(\mathrm{t})$, multiplet $(\mathrm{m})$. Elemental analyses $(\mathrm{C}, \mathrm{H}, \mathrm{N}$ ) were performed with a Perkin-Elmer 240 analyzer at the microanalyses Service of the Faculty of Pharmacy at Châtenay-Malabry (France). Mass spectra were obtained using a Bruker Esquire electrospray ionization apparatus. Thin-layer chromatography was performed on silica gel 60 
plates with a fluorescent indicator and visualized under a UVP Mineralight UVGL-58 lamp $(254 \mathrm{~nm})$ and with a $7 \%$ solution of phosphomolybdic acid in ethanol. Flash chromatography was performed using silica gel $60(40-63 \mu \mathrm{m}, 230-400$ mesh ASTM) at medium pressure (200 mbar). All solvents were distilled and stored over $4 \AA$ molecular sieves before use. All reagents were obtained from commercial suppliers unless otherwise stated. Organic extracts were, in general, dried over magnesium sulfate $\left(\mathrm{MgSO}_{4}\right)$ or sodium sulfate $\left(\mathrm{Na}_{2} \mathrm{SO}_{4}\right)$.

5-(1-(3-lodo-4-methoxyphenyl)vinyl)-1,2,3-trimethoxybenzene (5): To a THF solution of triphenylmethylphosphonium bromide (334 mg, $0.9 \mathrm{mmol}$ ) was slowly added $0.88 \mathrm{~mL}$ of a $1.06 \mathrm{M}$ solution of LiHMDS $(0.9 \mathrm{mmol})$ at $0^{\circ} \mathrm{C}$. The reaction mixture was stirred at this temperature for $1 \mathrm{~h}$. Then, $4(200 \mathrm{mg}, 0.5 \mathrm{mmol})$ in THF $(20 \mathrm{~mL})$ was added to the ylide solution and the resulting mixture stirred at $0^{\circ} \mathrm{C}$ for $1 \mathrm{~h}$. The reaction mixture was poured into water $(15 \mathrm{~mL})$ and extracted with $\mathrm{CH}_{2} \mathrm{Cl}_{2}$. The combined extracts were dried $\left(\mathrm{MgSO}_{4}\right)$ and concentrated. Purification by flash chromatography on silica ge afforded 5 as a pale yellow oil (192 mg, $90 \%) ; R_{f}=0.50\left(\mathrm{CH}_{2} \mathrm{Cl}_{2}\right) ;{ }^{1} \mathrm{H}$ $\operatorname{NMR}\left(\mathrm{CDCl}_{3}, 300 \mathrm{MHz}\right): \delta=4.07(\mathrm{~s}, 6 \mathrm{H}), 4.13(\mathrm{~s}, 3 \mathrm{H}), 4.15(\mathrm{~s}, 3 \mathrm{H})$, $5.60(\mathrm{~m}, 2 \mathrm{H}), 6.70(\mathrm{~s}, 2 \mathrm{H}), 7.03(\mathrm{dd}, J=8.5,1.7 \mathrm{~Hz}, 1 \mathrm{H}), 7.53(\mathrm{~d}, J=$ $8.5 \mathrm{~Hz}, 1 \mathrm{H}), 8.06(\mathrm{~d}, J=1.7 \mathrm{~Hz}, 1 \mathrm{H}) ;{ }^{13} \mathrm{C} \mathrm{NMR}\left(\mathrm{CDCl}_{3}, 75 \mathrm{MHz}\right): \delta=$ 56.1 (2C), 56.4, 60.9, 85.7, 105.5 (2C), 113.4, 110.2, 129.5, 135.7, 136.9, 137.8, 139.0, 148.2, 152.9 (2C), 157.7; IR = 2939; 1583, 1490 1461, 1263, 1126, $732 \mathrm{~cm}^{-1}$; MS (APCl+, m/z): $427[\mathrm{M}+\mathrm{H}]^{+}$; Anal. Calcd (\%) for $\mathrm{C}_{18} \mathrm{H}_{19} \mathrm{IO}_{4}$ : C 50.72, H 4.49, found: C 50.52, H 4.31.

(E)-Methyl 3-(2-methoxy-5- (1- (3,4,5-trimethoxyphenyl) vinyl) phenyl)acrylate (6): To a solution of $5(0.5 \mathrm{mmol})$ in DMF $(1.5 \mathrm{~mL})$ were slowly added at room temperature, $\mathrm{PdCl}_{2}\left(\mathrm{PPh}_{3}\right)_{2}(0.02 \mathrm{mmol})$, $\mathrm{Et}_{3} \mathrm{~N}(0.3 \mathrm{~mL})$, and methylacrylate $(0.4 \mathrm{~mL}, 4.7 \mathrm{mmol})$. The resulting mixture was stirred at $60^{\circ} \mathrm{C}$ for $72 \mathrm{~h}$. After cooling, $40 \mathrm{~mL}$ of EtOAc were added to the crude mixture which was washed with a saturated $\mathrm{NH}_{4} \mathrm{Cl}$ solution. After extraction with $\mathrm{CH}_{2} \mathrm{Cl}_{2}$, the combined extracts were dried $\left(\mathrm{MgSO}_{4}\right)$ and concentrated. Purification by flash chromatography on silica gel afforded 6 as a colorless oil $(123 \mathrm{mg}$ $64 \%) . \mathrm{R}_{\mathrm{f}}=0.18\left(\mathrm{CH}_{2} \mathrm{Cl}_{2}\right) .{ }^{1} \mathrm{H}$ NMR $\left(\mathrm{CDCl}_{3}, 300 \mathrm{MHz}\right): \delta=3.79(\mathrm{~s}$ $3 \mathrm{H}), 3.81(\mathrm{~s}, 6 \mathrm{H}), 3.89(\mathrm{~s}, 3 \mathrm{H}), 3.92(\mathrm{~s}, 3 \mathrm{H}), 5.37(\mathrm{~m}, 2 \mathrm{H}), 6.52(\mathrm{~d}, J=$ $16.1 \mathrm{~Hz}, 1 \mathrm{H}), 6.53(\mathrm{~s}, 2 \mathrm{H}), 6.89(\mathrm{~d}, J=8.6 \mathrm{~Hz}, 1 \mathrm{H}), 7.34(\mathrm{dd}, J=8.6$, $J=2.2 \mathrm{~Hz}, 1 \mathrm{H}), 7.51(\mathrm{~d}, J=2.2 \mathrm{~Hz}, 1 \mathrm{H}), 7.97(\mathrm{~d}, J=16.1 \mathrm{~Hz}, 1 \mathrm{H})$ ${ }^{13} \mathrm{C}$ NMR $\left(\mathrm{CDCl}_{3}, 75 \mathrm{MHz}\right): \delta=51.6,56.1(2 \mathrm{C}), 60.9,105.5(2 \mathrm{C})$, $110.8,113.1,118.7,123.0,128.8,131.3,133.8,137.0,137.9,140.1$ 149.0, 152.9 (2C), 158.1, 167.8, (one C missing); IR: 2944, 1838 $1714,1633,1500,1251,1169,1125 \mathrm{~cm}^{-1} . \mathrm{MS}(\mathrm{APCl}+\mathrm{m} / \mathrm{z}): 385$ $[\mathrm{M}+\mathrm{H}]^{+}$. Anal. Calcd for $\mathrm{C}_{22} \mathrm{H}_{24} \mathrm{O}_{6}: \mathrm{C} 68.74, \mathrm{H} 6.29$, found $\mathrm{C}$ 68.66, $\mathrm{H}$ 6.21 .

\section{(E)-3-(2-Methoxy-5-(1-(3,4,5-trimethoxyphenyl)vinyl)phenyl)} acrylic acid (7): Compound $6(0.1 \mathrm{mmol})$ in $\mathrm{MeOH}(2 \mathrm{~mL})$ was stirred with $0.12 \mathrm{~mL}$ of a $\mathrm{NaOH}(3 \mathrm{~N})$ solution for $3 \mathrm{~h}$ under reflux. After concentration in vacuo, the crude was washed with a saturated $\mathrm{NH}_{4} \mathrm{Cl}$ solution and extracted with $\mathrm{CH}_{2} \mathrm{Cl}_{2}$. The combined organic extracts were dried $\left(\mathrm{MgSO}_{4}\right)$ and concentrated. Purification by flash chromatography on silica gel afforded 7 as a pale yellow oil $(26 \mathrm{mg}$, $70 \%) ; \mathrm{R}_{\mathrm{f}}=0.15\left(\mathrm{CH}_{2} \mathrm{Cl}_{2} / \mathrm{EtOAc:} 9 / 1\right) ;{ }^{1} \mathrm{H}$ NMR $\left(\mathrm{CDCl}_{3}, 300 \mathrm{MHz}\right): \delta$ $=3.81(\mathrm{~s}, 6 \mathrm{H}), 3.90(\mathrm{~s}, 3 \mathrm{H}), 3.91(\mathrm{~s}, 3 \mathrm{H}), 5.38(\mathrm{~m}, 2 \mathrm{H}), 6.52(\mathrm{~d}, J=$ $16.0 \mathrm{~Hz}, 1 \mathrm{H}), 6.54(\mathrm{~s}, 2 \mathrm{H}), 6.90(\mathrm{~d}, J=8.5 \mathrm{~Hz}, 1 \mathrm{H}), 7.35$ (dd, $J=8.5$, $2.0 \mathrm{~Hz}, 1 \mathrm{H}), 7.52(\mathrm{~d}, J=2.0 \mathrm{~Hz}, 1 \mathrm{H}), 7.98(\mathrm{~d}, J=16.0 \mathrm{~Hz}, 1 \mathrm{H}), \mathrm{OH}$ not seen; ${ }^{13} \mathrm{C} \mathrm{NMR}\left(\mathrm{CDCl}_{3}, 75 \mathrm{MHz}\right): \delta=55.6,56.2(2 \mathrm{C}), 60.9,105.6$ (2C), 110.9, 113.2, 118.7, 123.0, 128.9, 131.4, 133.8, 137.1, 140.2, 149.1, 152.9 (3C), 158.1, 167.9; IR: 2953, 1658, 1635, 1502, 1241, $1122 \mathrm{~cm}^{-1}$. MS $(\mathrm{APCl}+, \mathrm{m} / \mathrm{z}): 371[\mathrm{M}+\mathrm{H}]^{+}$. Anal. Calcd for $\mathrm{C}_{21} \mathrm{H}_{22} \mathrm{O}_{6} \mathrm{C}$ 68.10, H 5.99, found C 67.89, 5.75;
(E)-3-(2-Methoxy-5-(1-(3,4,5-trimethoxyphenyl)vinyl)phenyl) prop2-en-1-ol (8): To a solution of 6 (254 $\mathrm{mg}, 0.664 \mathrm{mmol})$ in THF was slowly added at $-78^{\circ} \mathrm{C}, 0.89 \mathrm{~mL}$ of a $1.5 \mathrm{M}$ solution of DIBAH in $\mathrm{CH}_{2} \mathrm{Cl}_{2}$. After $30 \mathrm{~min}$ of stirring, the solution was poured into a saturated sodium tartrate in the presence of $0.1 \mathrm{~mL}$ of EtOAc. The mixture was stirred for $13 \mathrm{~h}$ at room temperature and extracted with $\mathrm{Et}_{2} \mathrm{O}$. The combined organic extracts were dried $\left(\mathrm{MgSO}_{4}\right)$ and concentrated. Purification by flash chromatography on silica gel afforded 8 as a pale yellow oil $\left(95 \mathrm{mg}, 40 \%\right.$ ); $\mathrm{R}_{\mathrm{f}}=0.38$ (Cyclohexane / EtOAc 5 / 5); ${ }^{1} \mathrm{H}$ NMR $\left(\mathrm{CDCl}_{3}, 300 \mathrm{MHz}\right): \delta=3.80(\mathrm{~s}, 6 \mathrm{H}), 3.86(\mathrm{~s}$, $3 \mathrm{H}), 3.88(\mathrm{~s}, 3 \mathrm{H}), 4.31(\mathrm{~d}, J=5.8 \mathrm{~Hz}, 2 \mathrm{H}), 5.31(\mathrm{~m}, 1 \mathrm{H}), 5.40(\mathrm{~m}, 1 \mathrm{H})$, $6.36(\mathrm{dt}, J=16.0 \mathrm{~Hz}, 5.8 \mathrm{~Hz}, 1 \mathrm{H}), 6.55(\mathrm{~s}, 2 \mathrm{H}), 6.83(\mathrm{~d}, J=8.5 \mathrm{~Hz}$, $1 \mathrm{H}), 6.91(\mathrm{~d}, J=16.0 \mathrm{~Hz}, 1 \mathrm{H}), 7.21(\mathrm{dd}, J=8.5,1.4 \mathrm{~Hz}, 1 \mathrm{H}), 7.44(\mathrm{~d}$, $J=1.4 \mathrm{~Hz}, 1 \mathrm{H}), \mathrm{OH}$ not seen; ${ }^{13} \mathrm{C}$ NMR $\left(\mathrm{CDCl}_{3}, 75 \mathrm{MHz}\right): \delta=55.4$, 56.0 (2C), 60.8, 64.0, 105.5 (2C), 110.3, 112.6 156.5, 125.2, 125.8, 126.9, 128.6, 129.6, 133.6, 137.3,137.6, 149.4, 152.7 (2C); IR: 2943 , $2368,1580,1500,1462,1412,1345,1245,1126,1007,845 \mathrm{~cm}^{-1}$. MS $\left(\mathrm{APCl}_{+}, \mathrm{m} / \mathrm{z}\right): 357[\mathrm{M}+\mathrm{H}]^{+}$. Anal. Calcd for $\mathrm{C}_{21} \mathrm{H}_{24} \mathrm{O}_{5} \mathrm{C} 70.77, \mathrm{H} 6.79$, found $\mathrm{C} 70.50, \mathrm{H} 6.69$.

General procedure for Suzuki couplings: To a solution of 5 (1 $\mathrm{mmol})$ in DME $(2 \mathrm{~mL})$ were added at room temperature, $2.5 \mathrm{mmol}$ of the required boronic acid, $\mathrm{NaHCO}_{3}(5 \mathrm{mmol}), 0.4 \mathrm{~mL}$ of $\mathrm{H}_{2} \mathrm{O}$ and $\mathrm{Pd}\left(\mathrm{PPh}_{3}\right)_{4}(0.06 \mathrm{mmol})$. The mixture was stirred for $18 \mathrm{~h}$ under reflux. After cooling, the solution was poured into a saturated $\mathrm{NH}_{4} \mathrm{Cl}$ solution $(15 \mathrm{~mL})$ and extracted with $\mathrm{CH}_{2} \mathrm{Cl}_{2}$. The combined extracts were dried $\left(\mathrm{MgSO}_{4}\right)$ and concentrated. Purification by flash chromatography on silica gel afforded compounds 9-16.

2,4'-Dimethoxy-5-[1-(3,4,5-trimethoxyphenyl)vinyl]biphenyl (9): Colorless oil; Yield (219 mg, $54 \%) ; R_{\mathrm{f}}=0.47\left(\mathrm{CH}_{2} \mathrm{Cl}_{2}\right) ;{ }^{1} \mathrm{H}$ NMR $\left(\mathrm{CDCl}_{3}, 300 \mathrm{MHz}\right): \delta=3.84-3.86(\mathrm{~m}, 9 \mathrm{H}), 3.87(\mathrm{~s}, 3 \mathrm{H}), 3.88(\mathrm{~s}, 3 \mathrm{H})$, $5.38(\mathrm{~m}, 2 \mathrm{H}), 6.60(\mathrm{~s}, 2 \mathrm{H}), 6.92-6.97(\mathrm{~m}, 3 \mathrm{H}), 7.27-7.30(\mathrm{~m}, 1 \mathrm{H}), 7.33$ $(\mathrm{d}, J=2.4 \mathrm{~Hz}, 1 \mathrm{H}), 7.46(\mathrm{~d}, J=9.0 \mathrm{~Hz}, 2 \mathrm{H}) ;{ }^{13} \mathrm{C} \mathrm{NMR}\left(\mathrm{CDCl}_{3}, 75\right.$ $\mathrm{MHz}): \delta=55.3,55.7,56.2(2 \mathrm{C}), 60.9,105.2,105.7(2 \mathrm{C}), 110.8,112.7$ 112.5 (2C), 133.8, 137.5 (2C), 128.1, 129.9, 130.6 (2C), 149.5, 152.9 (3C), 156.3, 158.8; IR: 2937, 2836, 1648, 1494, 1412, 1331, 1265, 1244, 1177, $1124 \mathrm{~cm}^{-1}$; MS (APCl+, m/z): $409[\mathrm{M}+\mathrm{H}]^{+}$; Anal. Calcd for $\mathrm{C}_{25} \mathrm{H}_{26} \mathrm{O}_{5}$ : C 73.87, H 6.45 found $\mathrm{C} 73.50, \mathrm{H} 6.29$.

2'-Methoxy-5'-[1-(3,4,5-trimethoxyphenyl)vinyl]biphenyl-4-ol (10): Brown oil; Yield (251. mg, $68 \%$ ); $R_{f}=0.33$ (Cyclohexane/EtOAc 7/3); ${ }^{1} \mathrm{H} \mathrm{NMR}\left(\mathrm{CDCl}_{3}, 300 \mathrm{MHz}\right): \delta=3.82(\mathrm{~s}, 6 \mathrm{H}), 3.83(\mathrm{~s}, 3 \mathrm{H}), 3.87(\mathrm{~s}, 3 \mathrm{H})$ $4.93(\mathrm{~s}, 1 \mathrm{H}), 5.37(\mathrm{~m}, 2 \mathrm{H}), 6.58(\mathrm{~s}, 2 \mathrm{H}), 6.86(\mathrm{~d}, J=8.7 \mathrm{~Hz}, 2 \mathrm{H}), 6.92$ $(\mathrm{d}, J=8.5 \mathrm{~Hz}, 1 \mathrm{H}), 7.28-7.31(\mathrm{~m}, 2 \mathrm{H}), 7.40(\mathrm{~d}, J=8.7 \mathrm{~Hz}, 2 \mathrm{H}) ;{ }^{13} \mathrm{C}$ NMR $\left(\mathrm{CDCl}_{3}, 75 \mathrm{MHz}\right): \delta=55.7,56.2(2 \mathrm{C}), 60.9,105.7(2 \mathrm{C}), 110.8$, $112.7,115.0$ (2C), 128.1, 129.9, 130.5, 130.6, 130.8 (2C), 133.8, 137.5, 149.5, 152.8 (3C), 154.9, 156.3; IR: 3428, 2938, 1580, 1502, 1236, $1126 \mathrm{~cm}^{-1}$; MS $(\mathrm{APCl}+\mathrm{m} / \mathrm{z}): 393[\mathrm{M}+\mathrm{H}]^{+}$; Anal. Calcd for $\mathrm{C}_{25} \mathrm{H}_{26} \mathrm{O}_{5}$ : C 73.87, $\mathrm{H} 6.45$ found $\mathrm{C} 73.61, \mathrm{H} 6.28$.

2-Methoxy-4'-nitro-5-[1-(3,4,5-trimethoxyphenyl)vinyl]-biphenyl (11): Yellow oil; Yield (236 mg, $56 \%) ; \mathrm{R}_{\mathrm{f}}=0.25\left(\mathrm{CH}_{2} \mathrm{Cl}_{2} /\right.$ Cyclohexane $5 / 5)^{1} \mathrm{H}$ NMR $\left(\mathrm{CDCl}_{3}, 300 \mathrm{MHz}\right): \delta=3.76(\mathrm{~s}, 6 \mathrm{H}), 3.80$ $(\mathrm{s}, 3 \mathrm{H}), 3.81(\mathrm{~s}, 3 \mathrm{H}), 5.32(\mathrm{~m}, 2 \mathrm{H}), 6.51(\mathrm{~s}, 2 \mathrm{H}), 6.91(\mathrm{~d}, J=8.3 \mathrm{~Hz}$, $1 \mathrm{H}), 7.19(\mathrm{~s}, 1 \mathrm{H}), 7.29(\mathrm{~m}, 1 \mathrm{H}), 7.62(\mathrm{~d}, J=8.0 \mathrm{~Hz}, 2 \mathrm{H}), 8.18(\mathrm{~d}, J=$ $8.0 \mathrm{~Hz}, 2 \mathrm{H}) ;{ }^{13} \mathrm{C}$ NMR $\left(\mathrm{CDCl}_{3}, 75 \mathrm{MHz}\right): \delta=55.7,56.2(2 \mathrm{C}), 60.9$, 105.7 (2C), 111.1, 113.2, 123.3 (2C), 128.0, 130.0, 130.4 (3C), 134.2, 137.1, 145.2, 149.1 (2C), 153.0 (3C), 156.2; IR : 2934, 1731, 1579, $1343,1235,1126 \mathrm{~cm}^{-1}$; MS $(\mathrm{APCl}+\mathrm{m} / \mathrm{z}): 422[\mathrm{M}+\mathrm{H}]^{+}$; Anal. Calcd for $\mathrm{C}_{24} \mathrm{H}_{23} \mathrm{NO}_{6}$ : C 68.40, H 5.50, N 3.32, found C 68.21, H 5.32, N 3.21. 
$3.88(\mathrm{~s}, 3 \mathrm{H}), 5.37(\mathrm{~m}, 2 \mathrm{H}), 6.56(\mathrm{~s}, 2 \mathrm{H}), 6.94(\mathrm{~m}, 1 \mathrm{H}), 7.27-7.38(\mathrm{~m}$ $4 \mathrm{H}), 7.45(\mathrm{~d}, J=8.4 \mathrm{~Hz}, 2 \mathrm{H}) ;{ }^{13} \mathrm{C}$ NMR $\left(\mathrm{CDCl}_{3}, 75 \mathrm{MHz}\right): \delta=55.7$ 56.2 (2C), 60.9, 105.7 (2C), 110.8, 112.9, 128.2 (2C), 128.9, 129.1 $130.5,130.8(2 \mathrm{C}), 133.0,133.9,136.7,149.3,137.3,152.9$ (3C) 156.2; IR: 2952, 1589, 1510, 1465, 1421, 1125, $732 \mathrm{~cm}^{-1}$; MS (APCl+, $\mathrm{m} / \mathrm{z}): 433,435[\mathrm{M}+\mathrm{Na}]^{+}$; Anal. Calcd for $\mathrm{C}_{24} \mathrm{H}_{23} \mathrm{ClO}_{4}: \mathrm{C} 70.15, \mathrm{H} 5.64$ found $\mathrm{C} 69.99, \mathrm{H} 5.51$.

4'-Fluoro-2-methoxy-5-[1-(3,4,5-trimethoxyphenyl)vinyl]-biphenyl (13): Colorless oil; Yield (201 mg, $51 \%$ ); $R_{f}=0.41$ (Cyclohexane EtOAc $8 / 2) ;{ }^{1} \mathrm{H}$ NMR $\left(\mathrm{CDCl}_{3}, 300 \mathrm{MHz}\right): \delta=3.82-3.88(\mathrm{~m}, 12 \mathrm{H})$, $5.38(\mathrm{~m}, 2 \mathrm{H}), 6.59(\mathrm{~s}, 2 \mathrm{H}), 6.95(\mathrm{~d}, J=9.0 \mathrm{~Hz}, 1 \mathrm{H}), 7.06-7.11(\mathrm{~m}, 2 \mathrm{H})$ 7.29-7.32 (m, 2H), 7.46-7.51 (m, 2H); ${ }^{19} \mathrm{~F} \mathrm{NMR}\left(\mathrm{CDCl}_{3}, 188 \mathrm{MHz}\right.$ decoupled): $\delta=-115.4 ;{ }^{13} \mathrm{C}$ NMR $\left(\mathrm{CDCl}_{3}, 75 \mathrm{MHz}\right): \delta=55.7,56.2$ (2C), 60.9, $105.7(2 \mathrm{C}), 110.8,112.8,114.8,115.0,128.6,129.3$ 130.6, 131.0, 131.1, 133.9, 134.2, 137.4, 149.4 (2C), 152.9 (3C) 156.2; IR: 1583, 1509, 1463, 1414, 1333, 1265, 1128, $732 \mathrm{~cm}^{-1}$; MS $(\mathrm{APCl}+, \mathrm{m} / \mathrm{z}): 397[\mathrm{M}+2 \mathrm{H}]^{+}$; Anal. Calcd for $\mathrm{C}_{24} \mathrm{H}_{23} \mathrm{FO}_{4}: \mathrm{C} 73.08, \mathrm{H}$ 5.88, found C $72.88, \mathrm{H} 5.71$.

2,3'-Dimethoxy-5-[1-(3,4,5-trimethoxyphenyl)vinyl]biphenyl (14): Yellow oil; Yield (284 mg, $70 \%$ ); $R_{f}=0.60$ (Cyclohexane / EtOAc $7 /$ 3); ${ }^{1} \mathrm{H}$ NMR $\left(\mathrm{CDCl}_{3}, 300 \mathrm{MHz}\right): \delta=3.77-3.79(\mathrm{~m}, 12 \mathrm{H}), 3.83(\mathrm{~s}, 3 \mathrm{H})$, $5.33(\mathrm{~m}, 2 \mathrm{H}), 6.54(\mathrm{~s}, 2 \mathrm{H}), 6.81-7.03(\mathrm{~m}, 1 \mathrm{H}), 7.05(\mathrm{~d}, J=6.6 \mathrm{~Hz}, 1 \mathrm{H})$ 7.03-7.06 (m, 2H), 7.20-7.31 (m, 3H); ${ }^{13} \mathrm{C} \mathrm{NMR}\left(\mathrm{CDCl}_{3}, 75 \mathrm{MHz}\right): \delta=$ 55.2, 55.7, 56.1 (2C), 60.9, 105.7 (2C), 110.8, 112.4, 112.7, 115.4 $122.0,128.5,128.9,130.1,130.7,133.7,137.4,137.8,139.7,149.4$ 152.9 (2C), 156.3, 159.2; IR: 2939, 2835, 1578, 1503, 1343, 1235 $1124 \mathrm{~cm}^{-1}$; MS $(\mathrm{APCl}+, \mathrm{m} / \mathrm{z}): 407[\mathrm{M}+\mathrm{H}]^{+}$; Anal. Calcd for $\mathrm{C}_{25} \mathrm{H}_{26} \mathrm{O}_{5}: \mathrm{C}$ 73.87, H 6.45, found D 73.52, H 6.20.

2-Methoxy-3'-nitro-5-[1-(3,4,5-trimethoxyphenyl)vinyl]-biphenyl (15): Yellow oil; Yield (60\%); $\mathrm{R}_{\mathrm{f}}=0.19$ (Cyclohexane / $\mathrm{CH}_{2} \mathrm{Cl}_{2} 5 / 5$ ); ${ }^{1} \mathrm{H} \mathrm{NMR}\left(\mathrm{CDCl}_{3}, 300 \mathrm{MHz}\right): \delta=3.83(\mathrm{~s}, 6 \mathrm{H}), 3.87(\mathrm{~s}, 3 \mathrm{H}), 3.88(\mathrm{~s}, 3 \mathrm{H})$, $5.40(\mathrm{~m}, 2 \mathrm{H}), 6.59(\mathrm{~s}, 2 \mathrm{H}), 6.99(\mathrm{~d}, J=7.9 \mathrm{~Hz}, 1 \mathrm{H}), 7.36(\mathrm{~m}, 2 \mathrm{H}), 7.56$ (t, $J=7.9 \mathrm{~Hz}, 1 \mathrm{H}), 7.82-7.86(\mathrm{~m}, 1 \mathrm{H}), 8.15-8.19(\mathrm{~m}, 1 \mathrm{H}), 8.41$ (t, $J=$ $1.9 \mathrm{~Hz}, 1 \mathrm{H}) ;{ }^{13} \mathrm{C}$ NMR $\left(\mathrm{CDCl}_{3}, 75 \mathrm{MHz}\right): \delta=55.7,56.2(2 \mathrm{C}), 60.9$ $105.7,111.0$ (2C), 113.2, 121.9, 124.6, 127.8, 128.9, 129.8, 130.4, 134.2, 135.6, 137.1, 140.0, 148.1, 149.1, 153.0 (3C),156.2; IR: 2939 $1578,1528,1503,1348,1234,1126 \mathrm{~cm}^{-1}$; MS (APCl+, m/z): 422 $[\mathrm{M}+\mathrm{H}]^{+}$; Anal. Calcd for $\mathrm{C}_{24} \mathrm{H}_{23} \mathrm{NO}_{6}$ : C 68.40, H 5.50, N 3.32, found C 68.26, H 5.35, N 3.20 .

\section{2,2'-Dimethoxy-5-(1-(3,4,5-trimethoxyphenyl)vinyl)-1,1'-biphenyl}

(16): Pale yellow oil; Yield (288 mg, $71 \%$ ); $R_{f}=0.60$ (Cyclohexane EtOAc $7 / 3) ;{ }^{1} \mathrm{H}$ NMR $\left(\mathrm{CDCl}_{3}, 300 \mathrm{MHz}\right): \delta=3.74(\mathrm{~s}, 3 \mathrm{H}), 3.77(\mathrm{~s}$ $3 \mathrm{H}), 3.80(\mathrm{~s}, 6 \mathrm{H}), 3.84(\mathrm{~s}, 3 \mathrm{H}), 5.33(\mathrm{~m}, 2 \mathrm{H}), 6.58(\mathrm{~s}, 2 \mathrm{H}), 6.89-6.99$ $(\mathrm{m}, 3 \mathrm{H}), 7.30-7.19(\mathrm{~m}, 4 \mathrm{H}) ;{ }^{13} \mathrm{C} \mathrm{NMR}\left(\mathrm{CDCl}_{3}, 75 \mathrm{MHz}\right): \delta=55.7,55.8$ 56.2 (2C), 60.9, 105.8 (2C), 110.6, 111.2, 112.5, 120.4, 127.4, 127.6 128.4, 128.7, 131.4 (2C), 133.1, 137.6, 149.5, 152.8 (3C), 156.9, 157.0; IR: 2935, 1578, 1503, 1461, 1237, 1124, $1029 \mathrm{~cm}^{-1}$; MS $\left(\mathrm{APCl}_{+}, \mathrm{m} / \mathrm{z}\right): 407[\mathrm{M}+\mathrm{H}]^{+}$; Anal. Calcd for $\mathrm{C}_{25} \mathrm{H}_{26} \mathrm{O}_{5} \mathrm{C} 73.87, \mathrm{H} 6.45$, found $\mathrm{C} 73.54 ; \mathrm{H} 6.21$.

General procedure for the preparation of alkynes 17-22 and 2426: To a THF solution $(25 \mathrm{~mL})$ of $\mathbf{5}(1 \mathrm{mmol})$ was added $\mathrm{NEt}_{3}(1.2 \mathrm{~mL})$, $\mathrm{PdCl}_{2}\left(\mathrm{PPh}_{3}\right)_{2}(0.05 \mathrm{mmol})$, Cul $(0.1 \mathrm{~mol})$. Then, the required alkyne (3 to $6 \mathrm{mmol})$ in THF $(25 \mathrm{~mL})$ was added to the mixture and stirred at $60^{\circ} \mathrm{C}$ for $16 \mathrm{~h}$. After cooling, $40 \mathrm{~mL}$ of EtOAc was added to the crude mixture which was washed with a saturated $\mathrm{NH}_{4} \mathrm{Cl}$ solution. After extraction with $\mathrm{CH}_{2} \mathrm{Cl}_{2}$, the combined extracts were dried $\left(\mathrm{MgSO}_{4}\right)$ and concentrated. Purification by flash chromatography on silica gel afforded alkynes.
3-(2-Methoxy-5-(1-(3,4,5-trimethoxyphenyl)vinyl)phenyl)prop-2yn-1-ol (17): Brown oil; Yield (177 mg, $50 \%) ; \mathrm{R}_{\mathrm{f}}=0.23\left(\mathrm{CH}_{2} \mathrm{Cl}_{2} /\right.$ EtOAc $9 / 1) ;{ }^{1} \mathrm{H}$ NMR $\left(\mathrm{CDCl}_{3}, 300 \mathrm{MHz}\right): \delta=3.75(\mathrm{~s}, 6 \mathrm{H}), 3.81(\mathrm{~s}$, $3 \mathrm{H}), 3.84(\mathrm{~s}, 3 \mathrm{H}), 4.46(\mathrm{~s}, 2 \mathrm{H}), 5.28(\mathrm{~m}, 2 \mathrm{H}), 6.45(\mathrm{~s}, 2 \mathrm{H}), 6.78(\mathrm{~d}, J=$ $8.5 \mathrm{~Hz}, 1 \mathrm{H}), 7.24(\mathrm{~m}, 1 \mathrm{H}), 7.37(\mathrm{~d}, J=2.3 \mathrm{~Hz}, 1 \mathrm{H}), \mathrm{OH}$ not seen; ${ }^{13} \mathrm{C}$ NMR $\left(\mathrm{CDCl}_{3}, 75 \mathrm{MHz}\right): \delta=51.8,55.9,56.1(2 \mathrm{C}), 60.9,81.8,91.0$, 105.6 (2C), 110.3, 111.4, 113.2, 129.9, 133.5, 133.8, 137.1, 148.8, 152.9 (3C), 159.7; IR: 3379, 2935, 1582, 1500, 1456, 1412, 1124, $1022 \mathrm{~cm}^{-1}$. MS $(\mathrm{APCl}+, \mathrm{m} / \mathrm{z}): 355[\mathrm{M}+\mathrm{H}]^{+}$; Anal. Calcd for $\mathrm{C}_{21} \mathrm{H}_{22} \mathrm{O}_{5}$ : C71.17, H 6.26, found C 71.00, H 6.12 .

4-(2-Methoxy-5-(1-(3,4,5-trimethoxyphenyl)vinyl)phenyl)but-3-yn1-ol (18): Yellow oil; Yield (169 mg, $46 \%) ; \mathrm{R}_{\mathrm{f}}=0.20\left(\mathrm{CH}_{2} \mathrm{Cl}_{2} /\right.$ EtOAc 6 / 4); ${ }^{1} \mathrm{H} \mathrm{NMR}\left(\mathrm{CDCl}_{3}, 300 \mathrm{MHz}\right): \delta=2.42(\mathrm{t}, J=6.3 \mathrm{~Hz}, 2 \mathrm{H}), 2.64(\mathrm{t}$, $J=6.3 \mathrm{~Hz}, 2 \mathrm{H}), 3.73(\mathrm{~s}, 6 \mathrm{H}), 3.79(\mathrm{~s}, 3 \mathrm{H}), 3.81(\mathrm{~s}, 3 \mathrm{H}), 5.26(\mathrm{~m}, 2 \mathrm{H})$, $6.44(\mathrm{~s}, 2 \mathrm{H}), 6.75(\mathrm{~d}, J=8.6 \mathrm{~Hz}, 1 \mathrm{H}), 7.15(\mathrm{dd}, J=8.6,2.2 \mathrm{~Hz}, 1 \mathrm{H})$, $7.32(\mathrm{~d}, J=2.2 \mathrm{~Hz}, 1 \mathrm{H})$, OH not seen; ${ }^{13} \mathrm{C} \mathrm{NMR}\left(\mathrm{CDCl}_{3}, 75 \mathrm{MHz}\right): \delta=$ $24.1,55.9,56.1$ (2C), 60.8, 60.9, 78.6, 91.0, $105.6(2 \mathrm{C}), 110.2,112.2$, 113.1, 133.1, 133.7, 137.2, 137.8, 148.9, 152.9 (3C), 159.7; IR: 3442, 936, 1579, 1499, 1461, 1411, 1342, $1123 \mathrm{~cm}^{-1}$; MS (APCl+, m/z): 369 $[\mathrm{M}+\mathrm{H}]^{+}$; Anal. Calcd for $\mathrm{C}_{22} \mathrm{H}_{24} \mathrm{O}_{5}$ : C 71.72, $\mathrm{H}$ 6.57, found 71.49, 6.33.

\section{5-(2-Methoxy-5-(1-(3,4,5-trimethoxyphenyl)vinyl)phenyl)pent-4-} yn-1-ol (19): Yellow oil; Yield (206 mg, $54 \%) ; \mathrm{R}_{\mathrm{f}}=0.20\left(\mathrm{CH}_{2} \mathrm{Cl}_{2} /\right.$ EtOAc $6 / 4) ;{ }^{1} \mathrm{H} \mathrm{NMR}\left(\mathrm{CDCl}_{3}, 300 \mathrm{MHz}\right): \delta=1.88(\mathrm{q}, J=6.8 \mathrm{~Hz}, 2 \mathrm{H})$, 2.60 (t, $J=6.8 \mathrm{~Hz}, 2 \mathrm{H}), 3.81(\mathrm{~m}, 8 \mathrm{H}), 3.88(\mathrm{~s}, 3 \mathrm{H}), 3.89(\mathrm{~s}, 3 \mathrm{H}), 5.34$ $(\mathrm{m}, 2 \mathrm{H}), 6.52(\mathrm{~s}, 2 \mathrm{H}), 6.81(\mathrm{~d}, J=8.6 \mathrm{~Hz}, 1 \mathrm{H}), 7.22(\mathrm{dd}, J=8.6,2.3$ $\mathrm{Hz}, 1 \mathrm{H}), 7.39(\mathrm{~d}, J=2.3 \mathrm{~Hz}, 1 \mathrm{H}), \mathrm{OH}$ not seen; ${ }^{13} \mathrm{C} \mathrm{NMR}\left(\mathrm{CDCl}_{3}, 75\right.$ $\mathrm{MHz}): \delta=16.8,31.3,55.9,56.15(2 \mathrm{C}), 60.9,62.3,77.3,93.9,105.6$ (2C), 110.1, 112.5, 113.0, 129.1, 133.1, 133.7, 137.2, 149.0, 152.9 (3C), 159.7; IR: 3532, 2935, 1579, 1501, 1462, 141, 1344, 1271, 1237, $1126 \mathrm{~cm}^{-1}$; MS $(\mathrm{APCl}+\mathrm{m} / \mathrm{z}): 383[\mathrm{M}+\mathrm{H}]^{+}$; Anal. Calcd for $\mathrm{C}_{23} \mathrm{H}_{26} \mathrm{O}_{5}: \mathrm{C} 72.23, \mathrm{H} 6.85$, found $\mathrm{C} 72.01, \mathrm{H} 6.57$.

6-(2-Methoxy-5-(1-(3,4,5-trimethoxyphenyl)vinyl)phenyl)hex-5-yn1-ol (20): Yellow oil; Yield (178 mg, $45 \%)$. $\mathrm{R}_{\mathrm{f}}=0.17\left(\mathrm{CH}_{2} \mathrm{Cl}_{2} / \mathrm{EtOAc}\right.$ 6 / 4). ${ }^{1} \mathrm{H} \mathrm{NMR}\left(\mathrm{CDCl}_{3}, 300 \mathrm{MHz}\right): \delta=1.73(\mathrm{~m}, 4 \mathrm{H}), 2.51(\mathrm{t}, J=6.5 \mathrm{~Hz}$ $2 \mathrm{H}), 3.71(\mathrm{t}, J=5.5 \mathrm{~Hz}, 2 \mathrm{H}), 3.80(\mathrm{~s}, 6 \mathrm{H}), 3.87(\mathrm{~s}, 3 \mathrm{H}), 3.89(\mathrm{~s}, 3 \mathrm{H})$, $5.34(\mathrm{~m}, 2 \mathrm{H}), 6.52(\mathrm{~s}, 2 \mathrm{H}), 6.81(\mathrm{~d}, J=8.6 \mathrm{~Hz}, 1 \mathrm{H}), 7.20(\mathrm{dd}, J=8.6$, $2.2 \mathrm{~Hz}, 1 \mathrm{H}), 7.39(\mathrm{~d}, J=2.2 \mathrm{~Hz}, 1 \mathrm{H}), \mathrm{OH}$ not seen; ${ }^{13} \mathrm{C} \mathrm{NMR}\left(\mathrm{CDCl}_{3}\right.$, $75 \mathrm{MHz}$ ): $\delta=19.5,24.9,31.9,55.9,56.1$ (2C), 60.9, 62.3, 76.8, 94.4, 105.6 (2C), 110.2, 112.7, 112.9, 129.0, 133.3, 133.7, 137.2, 149.0, 152.9 (3C), 159.6; IR: 3423, 2937, 1579, 1499, 1461, 1410, 1124, 1025, $1005 \mathrm{~cm}^{-1}$. MS $(\mathrm{APCl}+\mathrm{m} / \mathrm{z}): 397[\mathrm{M}+\mathrm{H}]^{+}$. Anal. Calcd for $\mathrm{C}_{24} \mathrm{H}_{28} \mathrm{O}_{5}: \mathrm{C}$ 72.70, $\mathrm{H} 7.12$, found C 72.48, H 6.99.

3-(2-Methoxy-5-(1-(3,4,5-trimethoxyphenyl)vinyl)phenyl)-N,Ndimethylprop-2-yn-1-amine (21): Brown oil; Yield (156 mg, $41 \%)$; $R_{f}$ $=0.11($ Cyclohexane / EtOAc $1 / 9) ;{ }^{1} \mathrm{H}$ NMR $\left(\mathrm{CDCl}_{3}, 300 \mathrm{MHz}\right): \delta=$ $2.31(\mathrm{~s}, 3 \mathrm{H}), 2.38(\mathrm{~s}, 3 \mathrm{H}), 3.51(\mathrm{~s}, 2 \mathrm{H}), 3.78(\mathrm{~s}, 6 \mathrm{H}), 3.86(\mathrm{~s}, 3 \mathrm{H}), 3.88$ (s, 3H), $5.85(\mathrm{~m}, 2 \mathrm{H}), 6.53(\mathrm{~s}, 2 \mathrm{H}), 6.82(\mathrm{~d}, J=8.5 \mathrm{~Hz}, 1 \mathrm{H}), 7.24$ (dd, $J=8.5,2.1 \mathrm{~Hz}, 1 \mathrm{H}), 7.46(\mathrm{~d}, J=2.1 \mathrm{~Hz}, 1 \mathrm{H}) ;{ }^{13} \mathrm{C} \mathrm{NMR}\left(\mathrm{CDCl}_{3}, 75\right.$ $\mathrm{MHz}): \delta=44.1,44.2,48.8,55.9,56.1(2 \mathrm{C}), 60.9,81.3,88.9,105.6$ (2C) $110.2,112.1,113.0,129.4,133.4,133.6,137.1,148.9,152.9$ (3C), 159.8; IR: 2939, 1579, 1500, 1461, 1410, 1344, $1126 \mathrm{~cm}^{-1}$; MS $(\mathrm{APCl}+, \mathrm{m} / \mathrm{z}): 382[\mathrm{M}+\mathrm{H}]^{+}$; Anal. Calcd for $\mathrm{C}_{23} \mathrm{H}_{27} \mathrm{NO}_{4}: \mathrm{C}$ 72.42, $\mathrm{H}$ 7.13 , N 3.67, found C 72.19, 7.06, N 3.59.

(2-(2-Methoxy-5-(1-(3,4,5-trimethoxyphenyl)vinyl)phenyl) ethynyl) trimethylsilane (22): Brown oil; Yield $(249 \mathrm{mg}, 63 \%) ; R_{f}=0.35$ (Cyclohexane / EtOAc $8 / 2)$; ${ }^{1} \mathrm{H}$ NMR $\left(\mathrm{CDCl}_{3}, 300 \mathrm{MHz}\right): \delta=0.26$ (s, $9 \mathrm{H}), 3.81(\mathrm{~s}, 6 \mathrm{H}), 3.88(\mathrm{~s}, 3 \mathrm{H}), 3.90(\mathrm{~s}, 3 \mathrm{H}), 5.30(\mathrm{~m}, 1 \mathrm{H}), 5.40(\mathrm{~m}$, $1 \mathrm{H}), 6.52(\mathrm{~s}, 2 \mathrm{H}), 6.81(\mathrm{~d}, J=8.7 \mathrm{~Hz}, 1 \mathrm{H}), 7.21-7.28(\mathrm{~m}, 1 \mathrm{H}), 7.48(\mathrm{~d}$, $J=2.3 \mathrm{~Hz}, 1 \mathrm{H}) \cdot{ }^{13} \mathrm{C} \mathrm{NMR}\left(\mathrm{CDCl}_{3}, 75 \mathrm{MHz}\right): \delta=0.1(3 \mathrm{C}), 55.9(2 \mathrm{C})$, $56.0,56.1,60.9,100.9,105.6(2 \mathrm{C}), 110.3,112.4,113.1,130.0,132.8$, 
133.9, 137.1, 137.1, 148.8, 152.2 (2C),160.0; MS (APCI+, m/z): 397 $[\mathrm{M}+\mathrm{H}]^{+}$. Anal. Calcd for $\mathrm{C}_{23} \mathrm{H}_{28} \mathrm{O}_{4} \mathrm{Si}$ : C 69.66, $\mathrm{H}$ 7.12, found $\mathrm{C} 69.51, \mathrm{H}$ 7.00 .

5-(1-(3-Ethynyl-4-methoxyphenyl)vinyl)-1,2,3-trimethoxybenzene (23): To a solution of $22(1 \mathrm{mmol})$ in THF $(6 \mathrm{~mL})$ was added at $0^{\circ} \mathrm{C}$ a $1 \mathrm{M}$ solution of TBAF $(2 \mathrm{~mL})$. After $12 \mathrm{~h}$ of stirring at room temperature the solution was extracted with $\mathrm{Et}_{2} \mathrm{O}$ and the combined extracts were dried $\left(\mathrm{MgSO}_{4}\right)$ and concentrated. Purification by flash chromatography on silica gel afforded 23 as a brown oil $(214 \mathrm{mg}$ $66 \%) ; \mathrm{R}_{\mathrm{f}}=0.14$ (Cyclohexane / EtOAc $\left.8 / 2\right) ;{ }^{1} \mathrm{H} \mathrm{NMR}\left(\mathrm{CDCl}_{3}, 300\right.$ $\mathrm{MHz}): \delta=3.30(\mathrm{~s}, 1 \mathrm{H}), 3.82(\mathrm{~s}, 6 \mathrm{H}), 3.88(\mathrm{~s}, 3 \mathrm{H}), 3.93(\mathrm{~s}, 3 \mathrm{H}), 5.30$ $(\mathrm{m}, 1 \mathrm{H}), 5.40(\mathrm{~m}, 1 \mathrm{H}), 6.52(\mathrm{~s}, 2 \mathrm{H}), 6.86(\mathrm{~d}, J=8.7 \mathrm{~Hz}, 1 \mathrm{H}), 7.30(\mathrm{dd}$ $J=8.7,2.3 \mathrm{~Hz}, 1 \mathrm{H}), 7.46(\mathrm{~d}, J=2.3 \mathrm{~Hz}, 1 \mathrm{H}) ;{ }^{13} \mathrm{C} \mathrm{NMR}\left(\mathrm{CDCl}_{3}, 75\right.$ $\mathrm{MHz}): \delta=55.9,56.1(2 \mathrm{C}), 60.9,79.9,81.1,105.6(2 \mathrm{C}), 110.3,110.9$ 113.2, 130.2, 160.3, 133.7, 133.8, 137.0, 152.9 (2C), 148.7 (one C missing); IR: $3300,2936,1579,1497,1415,1341,1272,1125,1002$, 897, $839 \mathrm{~cm}^{-1}$. MS $(\mathrm{APCl}+, \mathrm{m} / \mathrm{z}): 325[\mathrm{M}+\mathrm{H}]^{+}$. Anal. Calcd for $\mathrm{C}_{20} \mathrm{H}_{20} \mathrm{O}_{4}$ : C 74.06, H 6.21, found C 73.79, H 6.17.

1,2,3-Trimethoxy-5-(1-(4-methoxy-3-(2-(4-methoxyphenyl)ethynyl) phenyl)vinyl)benzene (24): Brown solid; Yield (344, 80 \%); m.p.: $105{ }^{\circ} \mathrm{C} ; \mathrm{R}_{\mathrm{f}}=0.35\left(\mathrm{CH}_{2} \mathrm{Cl}_{2}\right) ;{ }^{1} \mathrm{H}$ NMR $\left(\mathrm{CDCl}_{3}, 300 \mathrm{MHz}\right): \delta=3.78(\mathrm{~s}$, $3 \mathrm{H}), 3.81(\mathrm{~s}, 6 \mathrm{H}), 3.88(\mathrm{~s}, 3 \mathrm{H}), 3.91(\mathrm{~s}, 3 \mathrm{H}), 5.36(\mathrm{~m}, 2 \mathrm{H}), 6.55(\mathrm{~s}, 2 \mathrm{H})$ $6.84(\mathrm{~m}, 3 \mathrm{H}), 7.25(\mathrm{dd}, J=8.8,2.0 \mathrm{~Hz}, 1 \mathrm{H}), 7.52-7.46(\mathrm{~m}, 3 \mathrm{H}) ;{ }^{13} \mathrm{C}$ NMR $\left(\mathrm{CDCl}_{3}, 75 \mathrm{MHz}\right): \delta=55.1,55.8,56.0$ (2), 60.7, 84.1, 93.4, 105.5 (2C), 110.2, 112.4, 113.1, 113.8 (2C), 115.4, 129.24, 132.9 (3C), 133.6, 137.1, 148.8, 152.8 (3C), 159.4 (2C); IR: 2939, 2838 $1510,1462,1246,1126,906 \mathrm{~cm}^{-1}$. MS $(\mathrm{APCl}+\mathrm{m} / \mathrm{z}): 431[\mathrm{M}+\mathrm{H}]^{+}$. Anal. Calcd for $\mathrm{C}_{27} \mathrm{H}_{26} \mathrm{O}_{5}$ : C 75.33, H 6.09, found C 75.04, H 5.81.

1,2,3-Trimethoxy-5-(2-(2-methoxy-5-(1-(3,4,5-trimethoxyphenyl) vinyl)phenyl)ethynyl)benzene (25): Brown oil; Yield (345 mg, $74 \%$ ); $\mathrm{R}_{\mathrm{f}}=0.30$ (Cyclohexane / EtOAc 7/3); ${ }^{1} \mathrm{H} \mathrm{NMR}\left(\mathrm{CDCl}_{3}, 300 \mathrm{MHz}\right): \delta=$ $3.78(\mathrm{~s}, 3 \mathrm{H}), 3.80(\mathrm{~s}, 3 \mathrm{H}), 3.81(\mathrm{~s}, 6 \mathrm{H}), 3.84(\mathrm{~s}, 3 \mathrm{H}), 3.88(\mathrm{~s}, 3 \mathrm{H}), 3.91$ $(\mathrm{s}, 3 \mathrm{H}), 5.36(\mathrm{~m}, 2 \mathrm{H}), 6.55(\mathrm{~s}, 2 \mathrm{H}), 7.25(\mathrm{~s}, 2 \mathrm{H}), 7.30(\mathrm{~d}, J=8.7 \mathrm{~Hz}$ $1 \mathrm{H}), 7.48(\mathrm{dd}, J=8.7,2.0 \mathrm{~Hz}, 1 \mathrm{H}), 7.51(\mathrm{~d}, 1 \mathrm{H}, J=2.0 \mathrm{~Hz}) ;{ }^{13} \mathrm{C}$ NMR $\left(\mathrm{CDCl}_{3}, 75 \mathrm{MHz}\right): \delta=56.0,56.2(4 \mathrm{C}), 60.9(2 \mathrm{C}), 84.6,93.5,105.7$ (2C), 109.1 (2C), 110.4, 112.1, 113.1, 118.4, 129.7, 133.3, 133.8 , 137.2, 148.9, 152.9 (3C), 153.0 (3C), 159.6; IR: 2935, 1514, 1452, 1126; $725 \mathrm{~cm}^{-1}$; MS $\left(\mathrm{APCl}_{+}, \mathrm{m} / \mathrm{z}\right): 491[\mathrm{M}+\mathrm{H}]^{+}$; Anal. Calcd for $\mathrm{C}_{29} \mathrm{H}_{30} \mathrm{O}_{7}: \mathrm{C} 71.00, \mathrm{H} 6.16$, found C 70.79, H 6.02.

\section{1-(2-(2-Methoxy-5-(1-(3,4,5-trimethoxyphenyl)vinyl)phenyl)}

ethynyl)-4-(methoxymethoxy) benzene (26): Brown oil; Yield (349 $\mathrm{mg}, 80 \%) . \mathrm{R}_{\mathrm{f}}=0.45$ (Cyclohexane / EtOAc $\left.7 / 3\right) ;{ }^{1} \mathrm{H} \mathrm{NMR}\left(\mathrm{CDCl}_{3}\right.$ $300 \mathrm{MHz}): \delta=3.39(\mathrm{~s}, 3 \mathrm{H}), 3.73(\mathrm{~s}, 6 \mathrm{H}), 3.80(\mathrm{~s}, 3 \mathrm{H}), 3.84(\mathrm{~s}, 3 \mathrm{H})$, $5.10(\mathrm{~s}, 2 \mathrm{H}), 5.29(\mathrm{~m}, 2 \mathrm{H}), 6.47(\mathrm{~s}, 2 \mathrm{H}), 6.78(\mathrm{~d}, J=8.4 \mathrm{~Hz}, 1 \mathrm{H}), 6.91$ $(\mathrm{d}, J=8.4 \mathrm{~Hz}, 2 \mathrm{H}), 7.16-7.20(\mathrm{~m}, 1 \mathrm{H}), 7.39-7.43(\mathrm{~m}, 3 \mathrm{H}) ;{ }^{13} \mathrm{C}$ NMR $\left(\mathrm{CDCl}_{3}, 75 \mathrm{MHz}\right): \delta=56.0,56.1(2 \mathrm{C}), 56.3,60.9,84.4,93.4,94.3$, $105.6(2 \mathrm{C}), 110.3,112.4,113.1,116.1$ (2C), 116.7, 129.5, 133.1 (2C), 133.2, 133.7, 137.2, 149.0, 152.9 (3C), 157.2, 159.6; IR: 2936, 1579, 1508, 1461, 1411, 1341, 1279, 1233, 1079, $907 \mathrm{~cm}^{-1}$; MS (APCl+, $\mathrm{m} / \mathrm{z}): 461[\mathrm{M}+\mathrm{H}]^{+}$; Anal. Calcd for $\mathrm{C}_{28} \mathrm{H}_{28} \mathrm{O}_{6}: \mathrm{C} 73.03, \mathrm{H} \mathrm{6.13}, \mathrm{C} 72.88$, H 5.99 .

General protocol for Hydration of alkynes 17-20 and synthesis of 31-33: To an Emrys Optimizer 0.5-2 mL pyrex reaction vessel were added alkyne $(1 \mathrm{mmol})$ and PTSA $(0.1 \mathrm{mmol})$ in $\mathrm{EtOH}(1 \mathrm{~mL})$. The reaction vessel was then placed in the Emrys Optimizer and exposed to microwave irradiation according to the following specifications: temperature: $170^{\circ} \mathrm{C}$, time (30 min.), fixed hold time: on, sample absorption: high, pre-stirring: $60 \mathrm{~s}$. After cooling to room temperature, $\mathrm{H}_{2} \mathrm{O}(3 \mathrm{~mL})$ was added and the mixture was extracted with EtOAc $(3 \mathrm{x}$
$2 \mathrm{~mL}$ ). Organic layers were dried, concentrated and the crude mixture was purified by column chromatography on silica gel.

\section{3-Ethoxy-1-(2-methoxy-5-(1-(3,4,5-trimethoxyphenyl)vinyl)} phenyl)propan-1-one (27): Colorless oil; Yield (256 mg, $64 \%)$; $\mathrm{R}_{\mathrm{f}}=$ $0.45\left(\mathrm{CH}_{2} \mathrm{Cl}_{2} / \mathrm{EtOAc} 95 / 5\right) ;{ }^{1} \mathrm{H} \mathrm{NMR}\left(\mathrm{CDCl}_{3}, 300 \mathrm{MHz}\right): \delta=1.18(\mathrm{t}, J$ $=7.0 \mathrm{~Hz}, 3 \mathrm{H}), 3.29(\mathrm{t}, J=6.7 \mathrm{~Hz}, 2 \mathrm{H}), 3.51(\mathrm{q}, J=7.0 \mathrm{~Hz}, 2 \mathrm{H}), 3.79-$ $3.83(\mathrm{~m}, 8 \mathrm{H}), 3.87(\mathrm{~s}, 3 \mathrm{H}), 3.92(\mathrm{~s}, 3 \mathrm{H}), 5.37(\mathrm{~m}, 2 \mathrm{H}), 6.51(\mathrm{~s}, 2 \mathrm{H})$, $6.92(\mathrm{~d}, J=8.6 \mathrm{~Hz}, 1 \mathrm{H}), 7.41$ (dd, $J=2.4,8.6 \mathrm{~Hz}, 1 \mathrm{H}), 7.75(\mathrm{~d}, J=2.4$ $\mathrm{Hz}, 1 \mathrm{H}) ;{ }^{13} \mathrm{C}$ NMR $\left(\mathrm{CDCl}_{3}, 75 \mathrm{MHz}\right): \delta=15.1,44.1,55.7,56.1(2 \mathrm{C})$, $60.9,65.8,66.4,105.6(2 \mathrm{C}), 111.2,113.4,128.0,130.0,133.2,137.0$, 137.9, 148.8, 152.9 (3C), 158.3, 200.3; IR: 2934, 1673, 1579, 1497, 1461, 1409, 1124, $1009 \mathrm{~cm}^{-1}$; MS (APCl+, m/z): $401[\mathrm{M}+\mathrm{H}]^{+}$; Anal. Calcd for $\mathrm{C}_{23} \mathrm{H}_{28} \mathrm{O}_{6}$ : C 68.98, H 7.05, found C 68.58, H 6.79.

\section{4-Ethoxy-1-(2-methoxy-5-(1-(3,4,5-trimethoxyphenyl)vinyl)}

phenyl)butan-1-one (28): Colorless oil; Yield (270 mg, $63 \%) ; R_{f}=$ 0.15 (Cyclohexane / EtOAc $8 / 2) ;{ }^{1} \mathrm{H}$ NMR $\left(\mathrm{CDCl}_{3}, 300 \mathrm{MHz}\right): \delta=$ 1.16 (t, $J=7.0 \mathrm{~Hz}, 3 \mathrm{H}$ ), 1.96 (q, $J=7.0 \mathrm{~Hz}, 2 \mathrm{H}), 3.05$ (t, $J=7.2 \mathrm{~Hz}$, 2H), 3.42-3.49 (m, 4H), $3.79(\mathrm{~s}, 6 \mathrm{H}), 7.69(\mathrm{~d}, J=2.3 \mathrm{~Hz}, 1 \mathrm{H}), 3.86(\mathrm{~s}$, $3 \mathrm{H}), 3.90(\mathrm{~s}, 3 \mathrm{H}), 5.36(\mathrm{~m}, 2 \mathrm{H}), 6.51(\mathrm{~s}, 2 \mathrm{H}), 6.90(\mathrm{~d}, J=8.6 \mathrm{~Hz}, 1 \mathrm{H})$, 7.38 (dd, $J=8.6,2.3 \mathrm{~Hz}, 1 \mathrm{H}) ;{ }^{13} \mathrm{C}$ NMR $\left(\mathrm{CDCl}_{3}, 75 \mathrm{MHz}\right): \delta=15.1$, 25.5, 40.4, 55.6, 56.1 (2C), 60.8, 66.0, 69.8, 105.6 (2C), 111.2, 113.3, $128.4,129.7,132.8,133.7,136.9,137.9,148.8,152.9$ (2C), 158.0, 202.4; IR: 2934, 2857, 1673, 1600, 1578, 1496, 1462, 1409, 1344, 1235, $1008 \mathrm{~cm}^{-1}$; MS $(\mathrm{APCl}+, \mathrm{m} / \mathrm{z}): 415[\mathrm{M}+\mathrm{H}]^{+}$; Anal. Calcd for $\mathrm{C}_{24} \mathrm{H}_{30} \mathrm{O}_{6}: \mathrm{C} 69.54, \mathrm{H} 7.30$, found C 69.48, H 7.25.

\section{5-Ethoxy-1-(2-methoxy-5-[1-(3,4,5-trimethoxyphenyl)vinyl]} phenyl)pentan-1-one (29): Yellow oil; Yield (175 mg, $41 \%) ; R_{f}=$ 0.53 (Cyclohexane/EtOAc: 6/4); ${ }^{1} \mathrm{H}$ NMR $\left(\mathrm{CDCl}_{3}, 300 \mathrm{MHz}\right): \delta=1.18$ $(\mathrm{t}, J=7.2 \mathrm{~Hz}, 3 \mathrm{H}), 1.72-1.81(\mathrm{~m}, 2 \mathrm{H}), 3.00(\mathrm{t}, J=6.9 \mathrm{~Hz}, 2 \mathrm{H}), 3.41-$ $3.49(\mathrm{~m}, 4 \mathrm{H}), 3.80(\mathrm{~m}, 8 \mathrm{H}), 3.87(\mathrm{~s}, 3 \mathrm{H}), 3.91(\mathrm{~s}, 3 \mathrm{H}), 5.37(\mathrm{~m}, 2 \mathrm{H})$, $6.51(\mathrm{~s}, 2 \mathrm{H}), 6.91(\mathrm{~d}, J=8.4 \mathrm{~Hz}, 1 \mathrm{H}), 7.39$ (dd, $J=2.4,8.4 \mathrm{~Hz}, 1 \mathrm{H})$, $7.68(\mathrm{~d}, J=2.4 \mathrm{~Hz}, 1 \mathrm{H}),{ }^{13} \mathrm{C} \mathrm{NMR}\left(\mathrm{CDCl}_{3}, 75 \mathrm{MHz}\right): \delta=15.2,21.1$, 29.4, 43.5, 55.6, 56.1 (2), 60.9, 66.1, 70.4, 105.6 (2), 111.2, 113.4, 128.5, 129.7, 132.8, 133.8, 137.0, 148.8, 152.9 (3), 158.0, 202.9; IR: 2934, 1674, 1578, 1498, 1462, 1409, 1345, 1236, $1125 \mathrm{~cm}^{-1}$; MS $\left(\mathrm{APCl}_{+}, \mathrm{m} / \mathrm{z}\right): 429[\mathrm{M}+\mathrm{H}]^{+}$; Anal. Calcd for $\mathrm{C}_{25} \mathrm{H}_{32} \mathrm{O}_{6}: \mathrm{C} 70.07, \mathrm{H} 7.53$, found C 69.87, H 7.39.

\section{6-Hydroxy-1-(2-methoxy-5-(1-(3,4,5-trimethoxyphenyl)vinyl)}

phenyl)hexan-1-one (30) Colorless oil; Yield (283 mg, $64 \%)$; $R_{f}=$ 0.13 (Cyclohexane / EtOAc 6 / 4); ${ }^{1} \mathrm{H}$ NMR $\left(\mathrm{CDCl}_{3}, 300 \mathrm{MHz}\right): \delta=$ 1.39-1.47 (m, 2H), 1.56-1.65 (m, 4H), $2.99(\mathrm{t}, J=6,9 \mathrm{~Hz}, 2 \mathrm{H}), 3.65(\mathrm{t}$, $J=6.6 \mathrm{~Hz}, 2 \mathrm{H}), 3.80(\mathrm{~s}, 6 \mathrm{H}), 3.87(\mathrm{~s}, 3 \mathrm{H}), 3.92(\mathrm{~s}, 3 \mathrm{H}), 5.38(\mathrm{~m}, 2 \mathrm{H})$, $6.51(\mathrm{~s}, 2 \mathrm{H}), 6.91(\mathrm{~d}, J=8,7 \mathrm{~Hz}, 1 \mathrm{H}), 7.40(\mathrm{dd}, J=8.7,2.4 \mathrm{~Hz}, 1 \mathrm{H})$, 7.69 (d, $J=2.4 \mathrm{~Hz}, 1 \mathrm{H}), \mathrm{OH}$ not seen; ${ }^{13} \mathrm{C} \mathrm{NMR}\left(\mathrm{CDCl}_{3}, 75 \mathrm{MHz}\right): \delta=$ 23.9, 25.4, 32.5, 43.6, 55.7, 56.2 (2C), 62.7, 60.9, 105.6 (2C), 111.2, 113.4, 128.5, 129.7, 132.9, 133.8, 137.0, 148.8, 152.9 (3C), 158.0, 203.0; IR : 3375, 2932, 1672, 1579, 1497, 1462, 1236, $1179 \mathrm{~cm}^{-1}$; MS $\left(\mathrm{APCl}_{+}, \mathrm{m} / \mathrm{z}\right): 415[\mathrm{M}+\mathrm{H}]^{+}$; Anal. Calcd for $\mathrm{C}_{24} \mathrm{H}_{30} \mathrm{O}_{6} \mathrm{C}, 69.54 \mathrm{H}$ 7.30, found C 69.47, H 7.19.

2-(4-Methoxyphenyl)-5-(1-(3,4,5-trimethoxyphenyl)vinyl) benzofuran (31): Colorless oil; Yield (358 mg, 86\%); $R_{f}=0.27$ (Cyclohexane / EtOAc 8 / 2); ${ }^{1} \mathrm{H}$ NMR $\left(\mathrm{CDCl}_{3}, 300 \mathrm{MHz}\right): \delta=3.81(\mathrm{~s}$, $6 \mathrm{H}), 3.86(\mathrm{~s}, 3 \mathrm{H}), 3.90(\mathrm{~s}, 3 \mathrm{H}), 5.44(\mathrm{~m}, 2 \mathrm{H}), 6.60(\mathrm{~s}, 2 \mathrm{H}), 6.86(\mathrm{~s}, 1 \mathrm{H})$ $6.98(\mathrm{~d}, J=8.8 \mathrm{~Hz}, 2 \mathrm{H}), 7.27(\mathrm{dd}, J=8.5,1.8 \mathrm{~Hz}, 1 \mathrm{H}), 7.50(\mathrm{~d}, J=$ $8.5 \mathrm{~Hz}, 1 \mathrm{H}), 7.54(\mathrm{~s}, 1 \mathrm{H}), 7.80(\mathrm{~d}, J=8.8 \mathrm{~Hz}, 2 \mathrm{H}) ;{ }^{13} \mathrm{C} \mathrm{NMR}\left(\mathrm{CDCl}_{3}\right.$, $75 \mathrm{MHz}): \delta=55.3,56.1(2 \mathrm{C}), 60.9,99.7,105.7(2 \mathrm{C}), 110.4,114.3$ (2C), 120.4, 123.2, 124.5, 126.4, 129.4, 136.4, 137.8, 150.3, 152.9 (3C), 154.5, 156.7, 160.1; IR: 2937, 2835, 1613, 1578, 1504, 1249, $1124,1024,1006 \mathrm{~cm}^{-1}$. MS $\left(\mathrm{APCl}_{+}, \mathrm{m} / \mathrm{z}\right): 417[\mathrm{M}+\mathrm{H}]^{+}$; Anal. Calcd for $\mathrm{C}_{24} \mathrm{H}_{24} \mathrm{O}_{5}:$ C 74.98, H 5.81, found C 74.69, H 5.54. 
2-(3,4,5-Trimethoxyphenyl)-5-(1-(3,4,5-trimethoxyphenyl)vinyl) benzofuran (32): Colorless oil; Yield (390 mg, $82 \%) ; R_{f}=0.15$ $\left(\mathrm{CH}_{2} \mathrm{Cl}_{2}\right) ;{ }^{1} \mathrm{H}$ NMR $\left(\mathrm{CDCl}_{3}, 300 \mathrm{MHz}\right): \delta=3.81(\mathrm{~s}, 6 \mathrm{H}), 3.89(\mathrm{~s}, 3 \mathrm{H})$ $3.90(\mathrm{~s}, 3 \mathrm{H}), 3.96(\mathrm{~s}, 6 \mathrm{H}), 5.44(\mathrm{~m}, 2 \mathrm{H}), 6.59(\mathrm{~s}, 2 \mathrm{H}), 6.93(\mathrm{~s}, 1 \mathrm{H})$ $7.09(\mathrm{~s}, 2 \mathrm{H}), 7.28-7.31(\mathrm{~m}, 1 \mathrm{H}), 7.47(\mathrm{~d}, J=8.7 \mathrm{~Hz}, 1 \mathrm{H}), 7.54-7.55(\mathrm{~m}$ $1 \mathrm{H}) ;{ }^{13} \mathrm{C}$ NMR $\left(\mathrm{CDCl}_{3}, 75 \mathrm{MHz}\right): \delta=56.1(2 \mathrm{C}), 56.3(2 \mathrm{C}), 60.9,61.0$ $101.1,102.2$ (2C), 105.7 (2C), 110.6, 113.5, 120.6, 125.0, 125.9, 129.2, 136.6, 137.8, 150.2, 152.9 (3C), 153.6 (3C), 154.6, 156.4; IR 2937, 1571, 1500, 1463, 1412, 1342, 1236, 1122, $726 \mathrm{~cm}^{-1}$; MS $\left(\mathrm{APCl}_{+}, \mathrm{m} / \mathrm{z}\right): 477[\mathrm{M}+\mathrm{H}]^{+} ;$Anal. Calcd for $\mathrm{C}_{28} \mathrm{H}_{28} \mathrm{O}_{7}: \mathrm{C} 70.57, \mathrm{H} 5.92$, found $\mathrm{C} 70.49$, $\mathrm{H} 5.84$.

\section{4-(5-(1-(3,4,5-Trimethoxyphenyl)vinyl)benzofuran-2-yl)phenol} (33): Pale white oil; Yield (277 mg, $69 \%$ ); $R_{f}=0.10$ (Cyclohexane / EtOAc 8 / 2); ${ }^{1} \mathrm{H}$ NMR $\left(\mathrm{CDCl}_{3}, 300 \mathrm{MHz}\right): \delta=3.81(\mathrm{~s}, 6 \mathrm{H}), 3.90(\mathrm{~s}$, $3 \mathrm{H}), 5.44(\mathrm{~d}, J=7.8 \mathrm{~Hz}, 2 \mathrm{H}), 5.60(\mathrm{~s}, 1 \mathrm{H}), 6.60(\mathrm{~s}, 2 \mathrm{H}), 6.85(\mathrm{~s}, 1 \mathrm{H})$ $6.92(\mathrm{~d}, J=8.4 \mathrm{~Hz}, 2 \mathrm{H}), 7.24-7.28(\mathrm{~m}, 1 \mathrm{H}), 7.45(\mathrm{~d}, J=8.4 \mathrm{~Hz}, 1 \mathrm{H})$ $7.53(\mathrm{~d}, J=1.8 \mathrm{~Hz}, 1 \mathrm{H}), 7.75(\mathrm{~d}, J=8.4 \mathrm{~Hz}, 2 \mathrm{H}) ;{ }^{13} \mathrm{C} \mathrm{NMR}\left(\mathrm{CDCl}_{3}, 75\right.$ $\mathrm{MHz}): \delta=56.1(2 \mathrm{C}), 61.0,99.7,105.7(2 \mathrm{C}), 110.5,113.4,115.8(2 \mathrm{C})$ $120.4,123.3,124.5,126.6$ (2C), 129.4, 156.7, 136.4, 137.9, 150.3 152.8 (3C), 154.5, 156.3; IR: 3609, 2928, 1581, 1264, 1127, 732, 703 $\mathrm{cm}^{-1}$. MS $\left(\mathrm{APCl}_{+}, \mathrm{m} / \mathrm{z}\right): 403[\mathrm{M}+\mathrm{H}]^{+}, 441[\mathrm{M}+\mathrm{K}]^{+}$. Anal. Calcd for $\mathrm{C}_{25} \mathrm{H}_{22} \mathrm{O}_{5}: \mathrm{C} 74.51, \mathrm{H} 5.51$, found C 74.17, H 5.12.

\section{2-(2-Azidoethynyl)-1-methoxy-4-(1-(3,4,5-trimethoxyphenyl)vinyl)} benzene iso $\mathrm{N}_{3} \mathrm{CA}-4$ (34): At $0^{\circ} \mathrm{C}$, to a solution of iso $\mathrm{NH}_{2} \mathrm{CA}-4 \mathbf{2 b}(1$ $\mathrm{g}, 3.17 \mathrm{mmol})$ in acetone $(50 \mathrm{~mL})$ was added $\mathrm{HCl}(0.2 \mathrm{~N}, 50 \mathrm{~mL})$. After $20 \mathrm{~min}$ of stirring, $\mathrm{NaNO}_{2}(12.68 \mathrm{mmol})$ was added to the mixture for $20 \mathrm{~min}$ followed by the addition of $\mathrm{NaN}_{3}(40 \mathrm{mmol})$. After $15 \mathrm{~min}$ of stirring, the resulting mixture was poured onto $\mathrm{Et}_{2} \mathrm{O}(50 \mathrm{~mL})$ and water $(30 \mathrm{~mL})$. After extraction, the combined extracts were dried $\left(\mathrm{MgSO}_{4}\right)$ and concentrated. Purification by flash chromatography on silica gel afforded iso $\mathrm{N}_{3}$ CA-4 $\mathbf{3 4}$ as a yellow solid: Yield $(917 \mathrm{mg}, 85$ \%); m.p.: 83-85 ${ }^{\circ} \mathrm{C}$; $\mathrm{R}_{\mathrm{f}}=0.56$ (Cyclohexane / EtOAc $7 / 3$ ); ${ }^{1} \mathrm{H}$ NMR $\left(\mathrm{CDCl}_{3}, 300 \mathrm{MHz}\right): \delta=3.82(\mathrm{~s}, 6 \mathrm{H}), 3.88(\mathrm{~s}, 3 \mathrm{H}), 3.90(\mathrm{~s}, 3 \mathrm{H}), 5,30$ $(\mathrm{m}, 1 \mathrm{H}), 5.40(\mathrm{~m}, 1 \mathrm{H}), 6.52(\mathrm{~s}, 2 \mathrm{H}), 6.85(\mathrm{~d}, J=8.4 \mathrm{~Hz}, 1 \mathrm{H}), 7.04(\mathrm{~d}, J$ $=2.1 \mathrm{~Hz}, 1 \mathrm{H}), 7.07(\mathrm{dd}, J=8.4,2.1 \mathrm{~Hz}, 1 \mathrm{H}) ;{ }^{13} \mathrm{C} \mathrm{NMR}\left(\mathrm{CDCl}_{3}, 75\right.$ $\mathrm{MHz}): \delta=56.2,56.3(2 \mathrm{C}), 61.07,105.8(2 \mathrm{C}), 111.7,113.6,120.3$ 125.8, 132.1, 134.8, 137.1, 148.4, 149.0, 151.8, 153.1 (2C); IR: 2124 $1577,1503,1413,1341,1240,1120,1003,880,628 \mathrm{~cm}^{-1}$. MS (ESI+, $\mathrm{m} / \mathrm{z}): 364[\mathrm{M}+\mathrm{Na}]^{+}$; Anal. Calcd for $\mathrm{C}_{20} \mathrm{H}_{19} \mathrm{~N}_{3} \mathrm{O}_{4}: \mathrm{C}$ 63.33, H 5.61, N 12.31, found C 63.00, H 5.43, N 12.08 .

Synthesis of triazoles 35-37: $34(1 \mathrm{mmol})$ and the corresponding alkyne $(1 \mathrm{mmol})$ were mixed in $n-\mathrm{BuOH} / \mathrm{H}_{2} \mathrm{O}(1 / 1,10 \mathrm{~mL})$ in a sealed tube in the presence of $\mathrm{CuSO}_{4}-5 \mathrm{H}_{2} \mathrm{O}(0.01 \mathrm{mmol})$ and potassium ascorbate $(0.1 \mathrm{mmol})$. The mixture was then stirred for $13 \mathrm{~h}$ at $70^{\circ} \mathrm{C}$. After cooling, the crude was poured onto water $(16 \mathrm{~mL})$ at $0^{\circ} \mathrm{C}$ and the precipitate was filtered and washed with water. Purification by flash chromatography on silica gel afforded 35-37.

1-(2-Methoxy-5-(1-(3,4,5-trimethoxyphenyl)vinyl)phenyl)-4-(4methoxyphenyl)-1H-1,2,3-triazole (35): Pale yellow solid; m.p.: 125 $127^{\circ} \mathrm{C}$; Yield (381 mg, $\left.86 \%\right) ; R_{f}=0.49$ (Cyclohexane / EtOAc $5 / 5$ ); ${ }^{1} \mathrm{H}$ NMR $\left(\mathrm{CDCl}_{3}, 300 \mathrm{MHz}\right): \delta=3.81(\mathrm{~s}, 6 \mathrm{H}), 3.82(\mathrm{~s}, 3 \mathrm{H}), 3.87(\mathrm{~s}$ 3H), $3.91(\mathrm{~s}, 3 \mathrm{H}), 5.40(\mathrm{~m}, 1 \mathrm{H}), 5.45(\mathrm{~m}, 1 \mathrm{H}), 6.56(\mathrm{~s}, 2 \mathrm{H}), 6.96(\mathrm{~d}, J=$ $8.5 \mathrm{~Hz}, 2 \mathrm{H}), 7.05(\mathrm{~d}, J=8.6 \mathrm{~Hz}, 1 \mathrm{H}), 7.40(\mathrm{dd}, J=8.6,2.2 \mathrm{~Hz}, 1 \mathrm{H})$ $7.82(\mathrm{~d}, J=8.5 \mathrm{~Hz}, 2 \mathrm{H}), 7.86(\mathrm{~d}, J=2.2 \mathrm{~Hz}, 1 \mathrm{H}), 8.23(\mathrm{~s}, 1 \mathrm{H}) ;{ }^{13} \mathrm{C}$ NMR $\left(\mathrm{CDCl}_{3}, 75 \mathrm{MHz}\right): \delta=55.2,56.0(2 \mathrm{C}), 60.7,105.6(2 \mathrm{C}), 111.8$ $113.8,114.1$ (2C), 120.9, 123.2, 125.1, 126.0, 127.0 (2C), 129.6 $134.5,136.5,137.9,147.0,148.2,150.8,152.9$ (2C), 159.5, one C missing; IR: 2937, 1580, 1497, 1461, 1412, 1248, 1174, 1125, 1025, 907, $726 \mathrm{~cm}^{-1}$; MS $\left(\mathrm{APCl}_{+}, \mathrm{m} / \mathrm{z}\right): 474[\mathrm{M}+\mathrm{H}]^{+}$; Anal. Calcd for $\mathrm{C}_{26} \mathrm{H}_{25} \mathrm{~N}_{3} \mathrm{O}_{4}$ : C 70.41, H 5.68, N 9.47, found, C 70.05, H 5.43, N 9.28.
1-(2-Methoxy-5-(1-(3,4,5-trimethoxyphenyl)vinyl)phenyl)-4-(3,4,5trimethoxyphenyl)-1H-1,2,3-triazole (36): Pale yellow solid; m.p.: $157-159{ }^{\circ} \mathrm{C}$; Yield $(363 \mathrm{mg}, 68 \%) ; \mathrm{R}_{\mathrm{f}}=0.26$ (Cyclohexane / EtOAc 5 / 5); ${ }^{1} \mathrm{H}$ NMR $\left(\mathrm{CDCl}_{3}, 300 \mathrm{MHz}\right): \delta=3.81(\mathrm{~s}, 6 \mathrm{H}), 3.86(\mathrm{~s}, 3 \mathrm{H}), 3.87$ (s, 3H), $3.93(\mathrm{~s}, 9 \mathrm{H}), 5.40(\mathrm{~m}, 1 \mathrm{H}), 5.45(\mathrm{~m}, 1 \mathrm{H}), 6.56(\mathrm{~s}, 2 \mathrm{H}), 7.06(\mathrm{~d}$, $J=8.6 \mathrm{~Hz}, 1 \mathrm{H}), 7.12(\mathrm{~s}, 2 \mathrm{H}), 7.41(\mathrm{~d}, J=8.6 \mathrm{~Hz}, 1 \mathrm{H}), 7.83(\mathrm{~s}, 1 \mathrm{H})$, $8.25(\mathrm{~s}, 1 \mathrm{H}) ;{ }^{13} \mathrm{C}$ NMR $\left(\mathrm{CDCl}_{3}, 75 \mathrm{MHz}\right): \delta=56.1(2 \mathrm{C}), 56.2(3 \mathrm{C})$, $60.8(2 \mathrm{C}), 103.1(2 \mathrm{C}), 105.6(2 \mathrm{C}), 111.9,113.9,121.5,125.3,125.9$, $126.1,129.8,134.6,136.5,138.0,138.1,147.1,148.2,150.9,152.9$ (2C), 153.6 (2C); IR: 1585, 1499, 1463, 1234, 1122, 1011, $834 \mathrm{~cm}^{-1}$; MS (APCl+, m/z): $534[\mathrm{M}+\mathrm{H}]^{+}$; Anal. Calcd for $\mathrm{C}_{29} \mathrm{H}_{31} \mathrm{~N}_{3} \mathrm{O}_{7}: \mathrm{C} 65.28, \mathrm{H}$ 5.86, N 7.88, found C 65.07, H 5.62, N 7.64

\section{1-(2-Methoxy-5-(1-(3,4,5-trimethoxyphenyl)vinyl)phenyl)-4-}

phenyl-1H-1,2,3-triazole (37): White solid. m.p.: $113-115^{\circ} \mathrm{C}$; Yield (387 mg, $91 \%) ; R_{f}=0.30$ (Cyclohexane / EtOAc $\left.5 / 5\right) ;{ }^{1} \mathrm{H}$ NMR $\left(\mathrm{CDCl}_{3}, 300 \mathrm{MHz}\right): \delta=3.81(\mathrm{~s}, 6 \mathrm{H}), 3.87(\mathrm{~s}, 3 \mathrm{H}), 3.93(\mathrm{~s}, 3 \mathrm{H}), 3.98(\mathrm{~s}$, $3 \mathrm{H}), 5.42(\mathrm{~m}, 1 \mathrm{H}), 5.45(\mathrm{~m}, 1 \mathrm{H}), 6.54(\mathrm{~s}, 2 \mathrm{H}), 7.06(\mathrm{~d}, J=8.7 \mathrm{~Hz}, 1 \mathrm{H})$, $7.42(\mathrm{dd}, J=8.7,2.2 \mathrm{~Hz}, 1 \mathrm{H}), 7.88(\mathrm{~d}, J=2.2 \mathrm{~Hz}, 1 \mathrm{H}), 8.66(\mathrm{~s}, 1 \mathrm{H})$; ${ }^{13} \mathrm{C}$ NMR $\left(\mathrm{CDCl}_{3}, 75 \mathrm{MHz}\right): \delta=52.1,56.1$ (3C), 60.8, $105.6(2 \mathrm{C})$, $111.9,114.2,125.0,125.1,129.6,130.4,134.7,136.4,138.1,139.5$, 148.1, 150.5, 152.9 (2C), 161.2; IR: 2949, 1749, 1345, 1233, 1182, 1035, $766 \mathrm{~cm}^{-1}$; MS $\left(\mathrm{APCl}_{+}, \mathrm{m} / \mathrm{z}\right): 443[\mathrm{M}+\mathrm{H}]^{+}$; Anal. Calcd for $\mathrm{C}_{22} \mathrm{H}_{23} \mathrm{~N}_{3} \mathrm{O}_{6}$ : C 62.11, H 5.45, N 9.88, found C 61.89, H 5.26, N 9.56.

Synthesis of phenstatin derivatives 38 and 39: These compounds were prepared as for alkynes $\mathbf{1 7}$ and 18 from (3-iodo-4methoxyphenyl)(3,4,5-trimethoxyphenyl)methanone:

\section{(3-(3-Hydroxyprop-1-ynyl)-4-methoxyphenyl)(3,4,5-trimethoxy} phenyl)methanone (38): Brown solid; m.p.: $137-139{ }^{\circ} \mathrm{C}$; Yield $(249$ $\mathrm{mg}, 70 \%) ; \mathrm{R}_{\mathrm{f}}=0.30$ (Cyclohexane / EtOAc $\left.5 / 5\right) ;{ }^{1} \mathrm{H}$ NMR $\left(\mathrm{CDCl}_{3}\right.$, $300 \mathrm{MHz}): \delta=3.88(\mathrm{~s}, 6 \mathrm{H}), 3.94(\mathrm{~s}, 3 \mathrm{H}), 3.97(\mathrm{~s}, 3 \mathrm{H}), 4.54(\mathrm{~d}, J=3.3$ $\mathrm{Hz}, 2 \mathrm{H}), 6.96(\mathrm{~d}, J=8.7 \mathrm{~Hz}, 1 \mathrm{H}), 7.00(\mathrm{~s}, 2 \mathrm{H}), 7.82(\mathrm{dd}, J=8.7,2.1$ $\mathrm{Hz}, 1 \mathrm{H}), 7.91(\mathrm{~d}, J=2.1 \mathrm{~Hz}, 1 \mathrm{H}), \mathrm{OH}$ not seen; ${ }^{13} \mathrm{C} \mathrm{NMR}\left(\mathrm{CDCl}_{3}, 75\right.$ $\mathrm{MHz}): \delta=51.7,56.1,56.3(2 \mathrm{C}), 60.9,80.8,92.1,107.4(2 \mathrm{C}), 110.1$, $111.8,130.1,132.3,132.8,136.0,152.8(2 \mathrm{C}), 163.0,193.9$, one C missing; IR: $3401,1632,1568,1504,1415,1336,1274,1241,1127$, 1016, $760 \mathrm{~cm}^{-1} ; \mathrm{MS}(\mathrm{APCl}+\mathrm{m} / \mathrm{z}): 357[\mathrm{M}+\mathrm{H}]^{+}$; Anal. Calcd for $\mathrm{C}_{20} \mathrm{H}_{20} \mathrm{O}_{6}: \mathrm{C} 67.41, \mathrm{H} 5.66$, found C 67.39, H 5.63.

\section{(3-(4-Hydroxybut-1-ynyl)-4-methoxyphenyl)(3,4,5-trimethoxy} phenyl)methanone (39): Brown solid; m.p.: $131-133^{\circ} \mathrm{C}$; Yield $(285$ $\mathrm{mg}, 80 \%) ; \mathrm{R}_{\mathrm{f}}=0.20$ (Cyclohexane / EtOAc $\left.5 / 5\right) ;{ }^{1} \mathrm{H}$ NMR $\left(\mathrm{CDCl}_{3}\right.$, $300 \mathrm{MHz}): \delta=2.75(\mathrm{t}, J=6.1 \mathrm{~Hz}, 2 \mathrm{H}), 3.84(\mathrm{t}, J=6.1 \mathrm{~Hz}, 2 \mathrm{H}), 3.88$ $(\mathrm{s}, 6 \mathrm{H}), 3.94(\mathrm{~s}, 3 \mathrm{H}), 3.97(\mathrm{~s}, 3 \mathrm{H}), 6.95(\mathrm{~d}, J=8.6 \mathrm{~Hz}, 1 \mathrm{H}), 7.01(\mathrm{~s}$, 2H), $7.79(\mathrm{dd}, J=8.6,2.1 \mathrm{~Hz}, 1 \mathrm{H}), 7.89(\mathrm{~d}, J=2.1 \mathrm{~Hz}, 1 \mathrm{H}), \mathrm{OH}$ not seen; ${ }^{13} \mathrm{C}$ NMR $\left(\mathrm{CDCl}_{3}, 75 \mathrm{MHz}\right): \delta=24.3,56.4,56.5(3 \mathrm{C}), 61.0$, $90.7,92.0,107.7$ (2C), 110.1, 112.8, 130.3, 132.0, 133.1, 135.7, 153.1 (2C), 163.3, 194.2, one C missing; IR: 2366, 1582, 1500, 1414, $1333,1272,1127 \mathrm{~cm}^{-1}$; MS $(\mathrm{APCl}+, \mathrm{m} / \mathrm{z}): 371[\mathrm{M}+\mathrm{H}]^{+}$; Anal. Calcd for $\mathrm{C}_{21} \mathrm{H}_{22} \mathrm{O}_{6}: \mathrm{C} 68.10, \mathrm{H} 5.99$, found C 68.01, H 5.87.

\section{Acknowledgements}

The authors gratefully acknowledge support of this project by CNRS and MNESR for doctoral fellowship for C.M. and E.R.

Keywords: antitumors agents combretastatin A-4 isoCA-4 cytotoxicity inhibitors tubulin apoptosis

a) A. Jordan, J. A. Hadfield, N. J. Lawrence, A. T. McGown Med. Res. Rev. 1998, 18, 259-296; b) M. A. Jordan, L. Wilson, Nat. Rev. Cancer 2004, 4, 253-265; c) Q. Li, H. L. Sham, S. H 
Rosenberg, Annu. Rep. Med. Chem. 1999, 34, 139-148; d) E. von Angerer, Exp. Opin. Ther. Pat. 1999, 9, 1069-1081. a) E. Hamel, Med. Res. Rev. 1996, 16, 207-231; b) G. Bacher, T. Beckers, P. Emig, T. Klenner, B. Kutscher, B. Nickel, Pure Appl. Chem. 2001, 73, 1459-1464.

[3] a) L. M. Leoni, E. Hamel, D. Genini, H. Shih, C. J. Carrera, H. B. Cottam, D. A. Carson, J. Natl. Cancer Inst. 2000, 92, $217-$ 224; b) G. R. Pettit, B. Toki, D. L. Herald, P. Verdier-Pinard, M. R. Boyd, E. Hamel, R. K. Pettit, J. Med. Chem. 1998, 41, 16881695; d) Z. Q. Wang, D. L. Yang, A. K. Mohanakrishnan, P. E. Fanwick, P. Nampoothiri, E. Hamel, M. Cushman, J. Med. Chem. 2000, 43, 2419-2429

[4] G. R. Pettit, S. B. Singh, E. Hamel, C. M. Lin, D. S. Alberts, D. Garcia-Kendall, Experientia 1989, 45, 209-211.

[5] a) G. R. Pettit, M. R. Rhodes, D. L. Herald, E. Hamel, J. M. Schmidt, R. K. Pettit, J. Med. Chem. 2005, 48, 4087-4099; b) A McGown, B. Fox, Cancer Chemother. Pharmacol. 1990, 26, 7981.

a) A.M. Gaya, R. G.J. Rustin, Clin. Oncol. (R. Coll. Radiol.). 2005, 17, 277-290; b) P. Hinnen, F. A. Eskens, Br. J. Cancer 2007, 96, 1159-1165; c) D. M. Patterson, G. J. Rustin, Clin. Oncol. (R. Coll. Radiol.) 2007, 19, 443-456; d) D. W. Siemann, M. C. Bibby, G. G. Dark, A. P. Dicker, F. A. Eskens, M. R. Horsman, D. Marme, P. M. Lorusso, Clin. Cancer Res. 2005, 11, 416-420; e) G. M. Tozer, S. Akerman, N. A. Cross, P. R. Barber, M. A. Bjorndahl, O. Greco, S. Harris, S. A. Hill, D. J. Honess, C. R. Ireson, K. L. Pettyjohn, V. E. Prise, C. C. ReyesAldasoro, C. Ruhrberg, D. T. Shima, C. Kanthou, Cancer Res. 2008, 68, 2301-2311; f) G. M. Tozer, C. Kanthou, B. C. Baguley, Nat. Rev. Cancer 2005, 5, 423-435.

a) D. J. Chaplin, S. A. Hill, Int. J. Radiat. Oncology, Biol., Phys. 2002, 54, 1491-1496; b) G. R. Pettit, C. Temple, V. L. Narayanan, R. Varma, M. J. Simpson, M. R. Boyd, G. A. Rener, N. Bansal, Anti-cancer Drug Des. 1995, 10, 299-309.

[8] K. Ohsumi, R. Nakagawa, Y. Fukuda, T. Hatanaka, Y. Morinaga, Y. Nihei, K. Ohishi, Y. Suga, Y. Akiyama, T. Tsuji, J. Med. Chem. 1998, 41, 3022-3032.

[9] D.W. Siemann, J. C. Randall, S. L. Young, Vascular-Targeted Therapies in Oncology Ed. John Wiley \& Sons, Chichester, 2006, 325-339.

[10] D. M. Patterson, G. J. S. Rustin, Drug Future 2007, 32, 1025 1032.

[11] A. M. Rojiani, L. Li, L. Rise, D. W. Siemann, Acta Oncol. 2002 41, 98-105.

[12] G. R. Pettit, M. R. Rhodes, D. L. Herald, D. J. Chaplin, M. R Stratford, E. Hamel, R. K. Pettit, J. C. Chapuis, D. Oliva, Anticancer Drug Des. 1998, 13, 981-993.

[13] a) M. Alami, J.-D. Brion, O. Provot, J. F. Peyrat, S. Messaoudi, A. Hamze, A. Giraud, J. Bignon, J. Bakala, J.-M. Liu, WO 122620 A1, 2008. ; b) A. Giraud, O. Provot, A. Hamze, J. D. Brion, M. Alami, Tetrahedron Lett. 2008, 49, 1107-1110; c) N. L'Hermite, A. Giraud, O. Provot, J. F. Peyrat, M. Alami, J. D. Brion, Tetrahedron 2006, 62, 11994-12002; d) S. Messaoudi, B. Treguier, A. Hamze, O. Provot, J. F. Peyrat, J. R. De Losada, J. M. Liu, J. Bignon, J. Wdzieczak-Bakala, S. Thoret, J. Dubois, J. D. Brion, M. Alami, J. Med. Chem. 2009, 52, 4538-4542; e) C. Mousset, A. Giraud, O. Provot, A. Hamze, J. Bignon, J.-M. Liu, S. Thoret, J. Dubois, J.-D. Brion, M. Alami, Bioorg. Med. Chem. Lett. 2008, 18, 3266-3271; f) C. Mousset, O. Provot, A. Hamze, J. Bignon, J. D. Brion, M. Alami, Tetrahedron 2008, 64, 4287-
4294; g) O. Provot, A. Giraud, J. F. Peyrat, M. Alami, J. D. Brion, Tetrahedron Lett. 2005, 46, 8547-8550.

[14] a) A. Hamze, A. Giraud, S. Messaoudi, O. Provot, J. F. Peyrat J. Bignon, J. M. Liu, J. Wdzieczak-Bakala, S. Thoret, J. Dubois J. D. Brion, M. Alami, ChemMedChem 2009, 4, 1912-1924; b) B. Treguier, A. Hamze, O. Provot, J. D. Brion, M. Alami, Tetrahedron Lett. 2009, 50, 6549-6552.

[15] J.-X. Duan, X. Cai, F. Meng, L. Lan, C. Hart, M. Matteucci, J. Med. Chem. 2007, 50, 1001-1006.

[16] a) For example, Sandmeyer diazotization of 3'aminocombretastatin A-4 in the presence of $\mathrm{Nal}$ and $\mathrm{NaNO}_{2}$ at $0^{\circ} \mathrm{C}$ afforded the desired $3^{\prime}$-iodoCA-4 but as a mixture of inseparable $(E)$ and $(Z)$ isomers (unpublished results); b) K. G. Pinney, M. P. Mejia, V. M. Villalobos, B. E. Rosenquist, G. R. Pettit, P. Verdier-Pinard, E. Hamel, Bioorg. Med. Chem. 2000, 8, 2417-2425.

[17] a) M. Alami, F. Ferri, G. Linstrumelle, Tetrahedron Lett. 1993 34, 6403-6406; b) K. Sonogashira, Y. Tohda, N. Hagihara, Tetrahedron Lett. 1975, 16, 4467-4470.

[18] N. Olivi, E. Thomas, J. F. Peyrat, M. Alami, J. D. Brion, Synlett 2004, 2175-2179.

[19] G. Le Bras, O. Provot, J. F. Peyrat, M. Alami, J. D. Brion, Tetrahedron Lett. 2006, 47, 5497-5501.

[20] a) M. Jacubert, A. Hamze, O. Provot, J. F. Peyrat, J. D. Brion, M. Alami, Tetrahedron Lett. 2009, 50, 3588-3592; b) G. Le Bras, A. Hamze, S. Messaoudi, O. Provot, P. B. Le Calvez, J. D. Brion, M. Alami, Synthesis 2008, 1607-1611.

[21] M. Jacubert, O. Provot, J. F. Peyrat, A. Hamze, J. D. Brion, M. Alami, Tetrahedron 2010, 66, 3775-3787.

[22] J. D. Olszewski, M. Marshalla, M. Sabat, R. J. Sundberg, J. Org. Chem. 1994, 59, 4285-4296.

[23] a) S. Messaoudi, J. D. Brion, M. Alami, Adv. Synth. Catal. 2010, 352, 1677-1687; b) S. Messaoudi, J.-D. Brion, M. Alami, Mini Rev. Org. Chem. 2011, 8, in press.

[24] F. Zavala, D. Guenard, J. P. Robin, E. Brown, J. Med. Chem. 1980, 23, 546-549.

[25] K. M. Boatright, G. S. Salvesen, Curr. Opin. Cell. Biol. 2003, 15, 725-731.

[26] R. B. G. Ravelli, B. Gigant, P. A. Curmi, I. Jourdain, S. Lachkar, A. Sobel, M. Knossow, Nature 2004, 428, 198-202.

[27] a) S. Messaoudi, A. Hamze, O. Provot, B. Tréguier, J. Rodrigo De Losada, J. Bignon, J.-M. Liu, J. Wdzieczak-Bakala, S. Thoret, J. Dubois, J.-D. Brion, M. Alami, ChemMedChem 2011, 6, 488-497; b) T. L. Nguyen, C. McGrath, A. R. Hermone, J. C. Burnett, D. W. Zaharevitz, B. W. Day, P. Wipf, E. Hamel, R. Gussio, J. Med. Chem. 2005, 48, 6107-6116; c) N. M. O’Boyle, M. Carr, L. M. Greene, O. Bergin, S. M. Nathwani, T. McCabe, D. G. Lloyd, D. M. Zisterer, M. J. Meegan, J. Med. Chem. 2010 , 53, 8569-8584; d) R. Romagnoli, P. G. Baraldi, M. D. Carrion, O. Cruz-Lopez, M. Tolomeo, S. Grimaudo, A. Di Cristina, M. R. Pipitone, J. Balzarini, A. Brancale, E. Hamel, Bioorg. Med. Chem. 2010, 18, 5114-5122.

Received: ((will be filled in by the editorial staff))

Published online: ((will be filled in by the editorial staff) 
Entry for the Table of Contents (Please choose one layout)

Layout 1:

\section{FULL PAPERS}

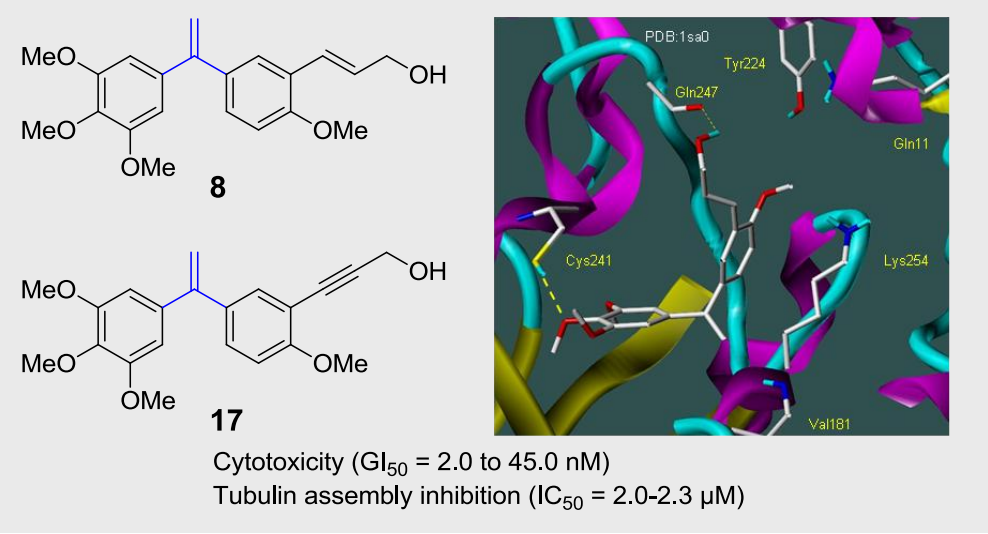

A. Hamze, E. Rasolofonjatovo, O. Provot ${ }^{*}$ C. Mousset, D. Veau, J. Rodrigo, J. Bignon, J.-M. Liu, J. Wdzieczak-Bakala, S. Thoret, J. Dubois, J.-D. Brion, M. Alami*

Page No. - Page No.

B-ring Modified isoCombretastatin A-4 Analogues Endowed with Interesting Anticancer Activities 